\title{
Psoriasis: From Pathogenesis to Pharmacological and Nano-Technological-Based Therapeutics
}

\author{
Robert Gironés Petit ${ }^{1}$, Amanda Cano ${ }^{1,2,3} \mathbb{D}^{\mathbb{D}}$, Alba Ortiz ${ }^{1,2}$, Marta Espina 1,2 $\mathbb{D}$, Josefina Prat ${ }^{1,2}$, \\ Montserrat Muñoz ${ }^{1,2}$, Patrícia Severino 4,5 ${ }^{\text {D }}$, Eliana B. Souto ${ }^{6,7, *(\mathbb{D})}$, Maria L. García ${ }^{1,2,3}$, Montserrat Pujol 1,2,* \\ and Elena Sánchez-López ${ }^{1,2,3, *(1)}$
}

1 Department of Pharmacy, Pharmaceutical Technology and Physical Chemistry, Faculty of Pharmacy, University of Barcelona, 08028 Barcelona, Spain; rgironpe7@alumnes.ub.edu (R.G.P.); acanofernandez@ub.edu (A.C.); albaortiz@ub.edu (A.O.); m.espina@ub.edu (M.E.); jprat@ub.edu (J.P.); mmunozjuncosa@ub.edu (M.M.); marisagarcia@ub.edu (M.L.G.)

2 Institute of Nanoscience and Nanotechnology, Universitat de Barcelona, 08028 Barcelona, Spain

3 Center for Biomedical Research in Neurodegenerative Diseases Network, Carlos III Health Institute, 28031 Madrid, Spain

4 University of Tiradentes (Unit) Av. Murilo Dantas, Aracaju 49010-390, Brazil; patricia_severino@itp.org.br 5 Institute of Technology and Research (ITP) Av. Murilo Dantas, Aracaju 49010-390, Brazil

6 CEB - Centre of Biological Engineering, Campus de Gualtar, University of Minho, 4710-057 Braga, Portugal

7 Faculty of Pharmacy, University of Coimbra, Pólo das Ciências da Saúde, Azinhaga de Santa Comba, 3000-548 Coimbra, Portugal

Citation: Petit, R.G.; Cano, A.; Ortiz A.; Espina, M.; Prat, J.; Muñoz, M.; Severino, P.; Souto, E.B.; García, M.L.; Pujol, M.; et al. Psoriasis: From Pathogenesis to Pharmacological and Nano-Technological-Based

Therapeutics. Int. J. Mol. Sci. 2021, 22 , 4983. https://doi.org/10.3390/ijms 22094983

Academic Editors: Naoko Kanda, Andrzej Slominski and Cristina Albanesi

Received: 23 March 2021

Accepted: 6 May 2021

Published: 7 May 2021

Publisher's Note: MDPI stays neutral with regard to jurisdictional claims in published maps and institutional affiliations.

Copyright: (c) 2021 by the authors. Licensee MDPI, Basel, Switzerland. This article is an open access article distributed under the terms and conditions of the Creative Commons Attribution (CC BY) license (https:// creativecommons.org/licenses/by/ $4.0 /)$.
* Correspondence: eliana.souto@ceb.uminho.pt (E.B.S.); mopujol@ub.edu (M.P.); esanchezlopez@ub.edu (E.S.-L.)

Abstract: Research in the pathogenesis of inflammatory skin diseases, such as skin dermatitis and psoriasis, has experienced some relevant breakthroughs in recent years. The understanding of age-related factors, gender, and genetic predisposition of these multifactorial diseases has been instrumental for the development of new pharmacological and technological treatment approaches. In this review, we discuss the molecular mechanisms behind the pathological features of psoriasis, also addressing the currently available treatments and novel therapies that are under clinical trials. Innovative therapies developed over the last 10 years have been researched. In this area, advantages of nanotechnological approaches to provide an effective drug concentration in the disease site are highlighted, together with microneedles as innovative candidates for drug delivery systems in psoriasis and other inflammatory chronic skin diseases.

Keywords: skin inflammatory diseases; psoriasis; psoriasis versus atopic dermatitis; biodegradable nanoparticles; microneedles; clinical trials

\section{Introduction}

Psoriasis is an inflammatory skin disorder that mainly depends on genetic predisposition and ageing. However, there are some environmental risk factors, such as trauma (e.g., Koebner phenomenon), infection, and drugs, that have been proposed to influence the development of this inflammatory skin disease. This pathology affects around $2 \%$ of the population worldwide, but it shows some variability, depending on the type of skin [1]. In this sense, in Caucasian and Scandinavian people, it increases its prevalence, rising until $11 \%$ of their population is affected [2]. Several types of psoriasis have been identified, depending on how it affects the patient. The majority of psoriasis cases correspond to psoriasis vulgaris or plaque-type psoriasis (almost 90\%). Plaque-type psoriasis is easily recognised by the pruritic plaques covered in silvery scales [3]. Innate and adaptative immune responses are responsible for the development of psoriatic inflammation, while innate immune responses are more significant in plaque-type psoriasis [4]. One of the 
most accepted mechanisms involves an overexpression of antimicrobial peptides in psoriatic skin, acting as a trigger and a continued maintenance phase [5]. Some of the most studied hallmarks of psoriasis are LL-37, $\beta$-defensins, and S100 proteins [6]. In the earlier phase, there is an abnormal decease of LL-37 and different antimicrobial peptides from keratinocytes in stress conditions, such as physical injury. LL-37 is released by damaged keratinocytes and forms complexes with genetic material from damaged cells around the keratinocyte. LL-37 has been recognised as a participant in the pathogenesis of the psoriasis, due to the boundaries with DNA-stimulating toll-like receptor 9 in plasmacytoid dendritic cells [7]. There are two ways in which LL-37 affects the activation of plasmatic dendritic cells. On the one hand, the stimulated production of type I IFN, which promotes phenotypic maturation of myeloid dendritic cells, has an important role in Th1 and Th17 differentiation and function [6-8]. Th-17 cells are special populations of CD4+ T cells that produce IL-17, IL-22, IL-21, TNF- $\alpha$, and other cytokines and express lineage specific transcription factor Retinoic acid receptor-Related Orphan receptor (RORC) $[9,10]$. The family of Th-17 cells includes several cell types, all of them expressing ROR- $\gamma \mathrm{t}$ and IL-23R. In a study published in 2018, the authors determined the mRNA expression level of RORC in patients with psoriasis and found significantly higher gene expression of RORC in patients with psoriasis than in control patients, thus concluding that Th-17 plays a role in the pathogenesis of the disease [11]. ROR $\gamma \mathrm{T}$ and its isoform, ROR, are encoded by a single gene called Rorg (also known as Rorc). Both isoforms use the last 9 exons (exons 3-11) of the Rorg gene, but the other exons used by them are different. Consequently, the ROR $\gamma \mathrm{T}$ mRNA differs from that of ROR in the first $100 \mathrm{nt}$, which translates into distinct $\mathrm{N}$-terminal amino acid sequences [12]. Expression of ROR $\gamma \mathrm{t}$ is not only confined to Th17 cells, but also regulates cytokine production in other cell types, such as CD8+Tc17 cells, invariant natural killer T cells, ILC3, and $\gamma \delta$ T-cells [13]. All of these contribute to autoimmune tissue inflammation. Moreover, it has been found that ROR $\gamma$-deficient mice show diminished Th17/IL-17 responses and are protected against autoimmune inflammatory diseases, such as psoriasis-like skin inflammation [14]. Pharmacological modulation of $\mathrm{ROR} \gamma \mathrm{t}$ by low molecular weight inhibitors is therefore an attractive approach to inhibit the proinflammatory IL-17/IL-23 axis. Given the fact that it is a nuclear hormone receptor, the activity of ROR $\gamma \mathrm{t}$ is regulated in a ligand-dependent manner. Therefore, numerous inhibitors targeting the ligand binding domain (LBD) of ROR $\gamma$ t have been reported recently. These drugs were effective in suppressing the IL-17 pathway and showed good efficacy in different inflammatory autoimmune disease rodent models [15].

Th- 17 cells are activated by IL-6, IL-1 $\beta$, and IL-23 and trigger chronic inflammation and autoimmunity, while TGF- $\beta$ and IL- 6 activated Th- 17 cells are weakly pathogenic and are mostly involved in tissue integrity and defense [16]. On the other hand, LL-37 complexed with DNA or RNA stimulates plasmacytoid dendritic cells through both TLR9 and TLR7. Furthermore, there are slan+ monocytes secreting high amounts of (TNF)- $\alpha$, IL-23, and IL-12, responding to the LL-37-RNA complexes. There is also migration of myocytic dendritic cells into lymph nodes with an extra proliferation of (TNF)- $\alpha$, IL-23, and IL-12 [17].

The maintenance phase of psoriatic inflammation is driven by the activation of the adaptative immune response via the $\mathrm{T}$ cell subsets [18]. The proliferation of keratinocytes in epidermis is engaged by two different vias, inflammation by action of TNF- $\alpha$, IL-17 and IFN- $\gamma$, and LL-37 complexed with DNA, resulting in an increasing production of type I IFNs [4]. All these mediators further maintain keratinocytes activation, producing LL-37, proinflammatory cytokines (TNF- $\alpha$, IL-1 $\beta$, IL-6), chemokines, and S100 proteins, propagating the chronic inflammation. Altogether, these promote keratinocyte proliferation and production of AMPs and chemokines, which promote neutrophil recruitment and sustain skin inflammation [19]. Figure 1 depicts the plaque-type psoriasis pathogenesis main hypothesis. 


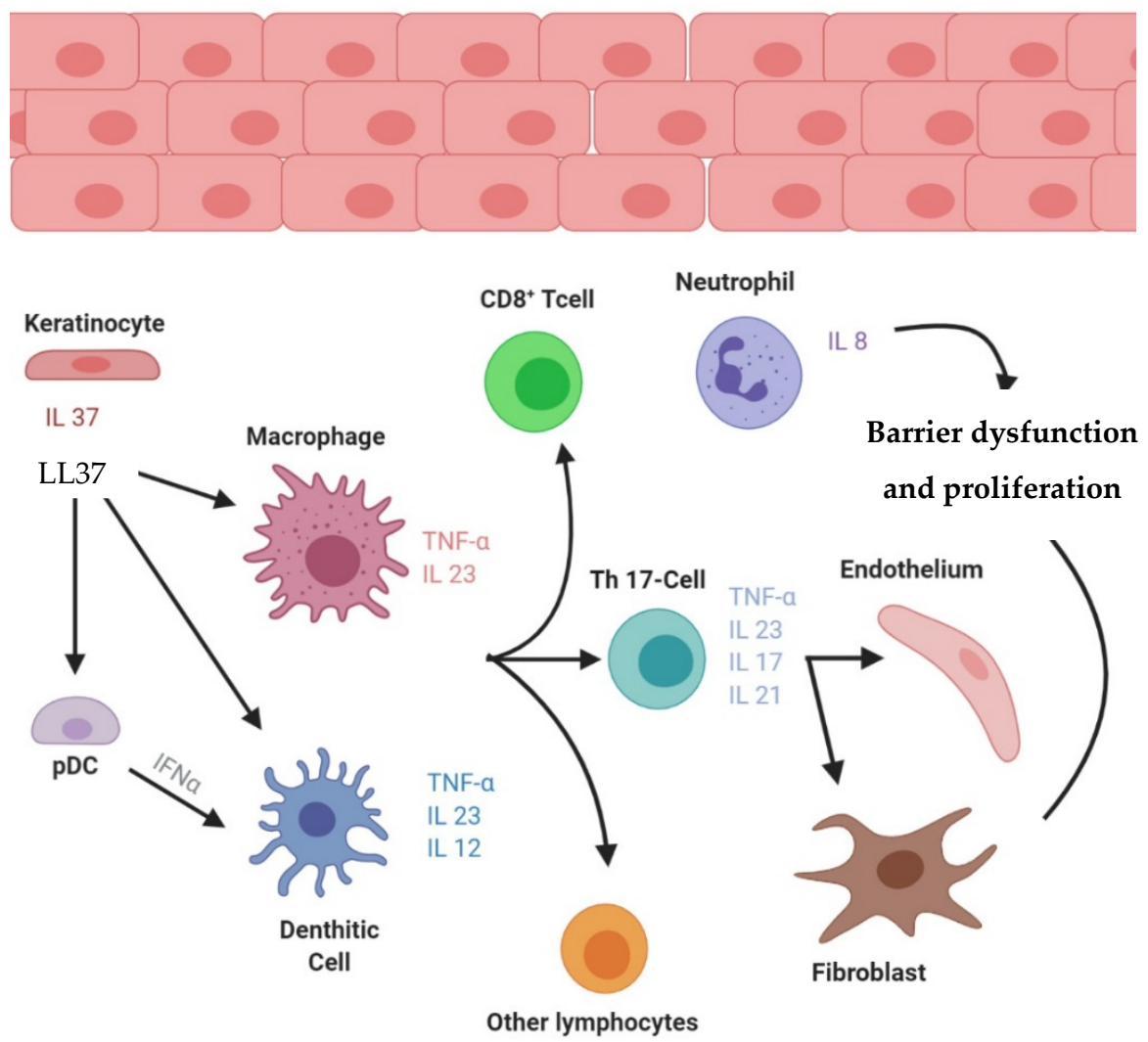

Figure 1. Plaque-type psoriasis pathogenesis principal hypothesis.

Plaque-type psoriasis is characterised by the inflammatory pathway TNF $\alpha-\mathrm{IL}-23-$ Th17. There are several types of IL-17, which are produced by different cell-types, such as hematopoietic cells, namely CD8+ T cells (Tc17), invariant NKT cells, $\gamma \delta \mathrm{T}$ cells, non-T non-B lymphocytes (termed type 3 innate lymphoid cells), and neutrophils. Inflammatory responses are regulated by IL-17A-F cytokines [20]. It has been stablished that the most important signalling in psoriasis is mediated by a receptor that could be activated by two different cytokines, IL-17A and IL-17F, IL-17A having a stronger effect [20]. Additionally, there is a recruitment of the ACT1 adaptor protein when IL-17A binds to the receptor complex, composed of IL-17RA subunits and one IL-17RC subunit.

There is an activation of some intracellular kinases with the interaction between ACT1 and the IL-17 receptor complex. These intracellular kinases include extracellular signalregulated kinase (ERK), p38 MAPK, TGF-beta-activated Kinase 1 (TAK1), I-kappa B kinase (IKK), and glycogen synthase kinase 3 beta (GSK-3 beta). All these kinases enable proinflammatory cytokines, chemokines, and antimicrobial peptides. Th1 and Th2 cytokines act through Janus kinase (JAK)-STAT signalling pathways, whereas Th17 responses are mediated by ACT1 and NFKB [21]. Alternatively, $\gamma \delta \mathrm{T}$ cells are able to produce IL-17A independently of the IL-23 stimulus [22].

The second most common psoriasis type is pustular psoriasis, which is characterized by multiple coalescing sterile pustules. Whilst in plaque psoriasis, the adaptative immune system has a greater importance in the pathogenesis, obtaining good results with therapies targeting these elements $[23,24]$. It seems that the innate immune system plays an important role in pustular psoriasis [8] and those therapies used in plaque psoriasis are less effective [25]. Although there is an overlapping of some metabolic paths, there are significant differences in the general pathogenesis of these psoriasis types. It seems that GPP principally depends on the activities of KCs, neutrophils, and monocytes [26]. There is an increased expression of IL-1 $\beta$, IL-36 $\alpha$, and IL-36 $\gamma$ in pustular psoriasis than in plaque psoriasis due to a mutation in gene IL $36 \mathrm{RN}$ [26]. This overexpression of IL-36 appears to be the central mechanism that promotes neutrophil accumulation in the epidermis $[27,28]$ 
(Figure 2). The significant presence of neutrophil chemokines CXCL1, CXCL2, and CXCL8 (IL-8) is in accordance with the assumed pathogenesis of GPP [26].

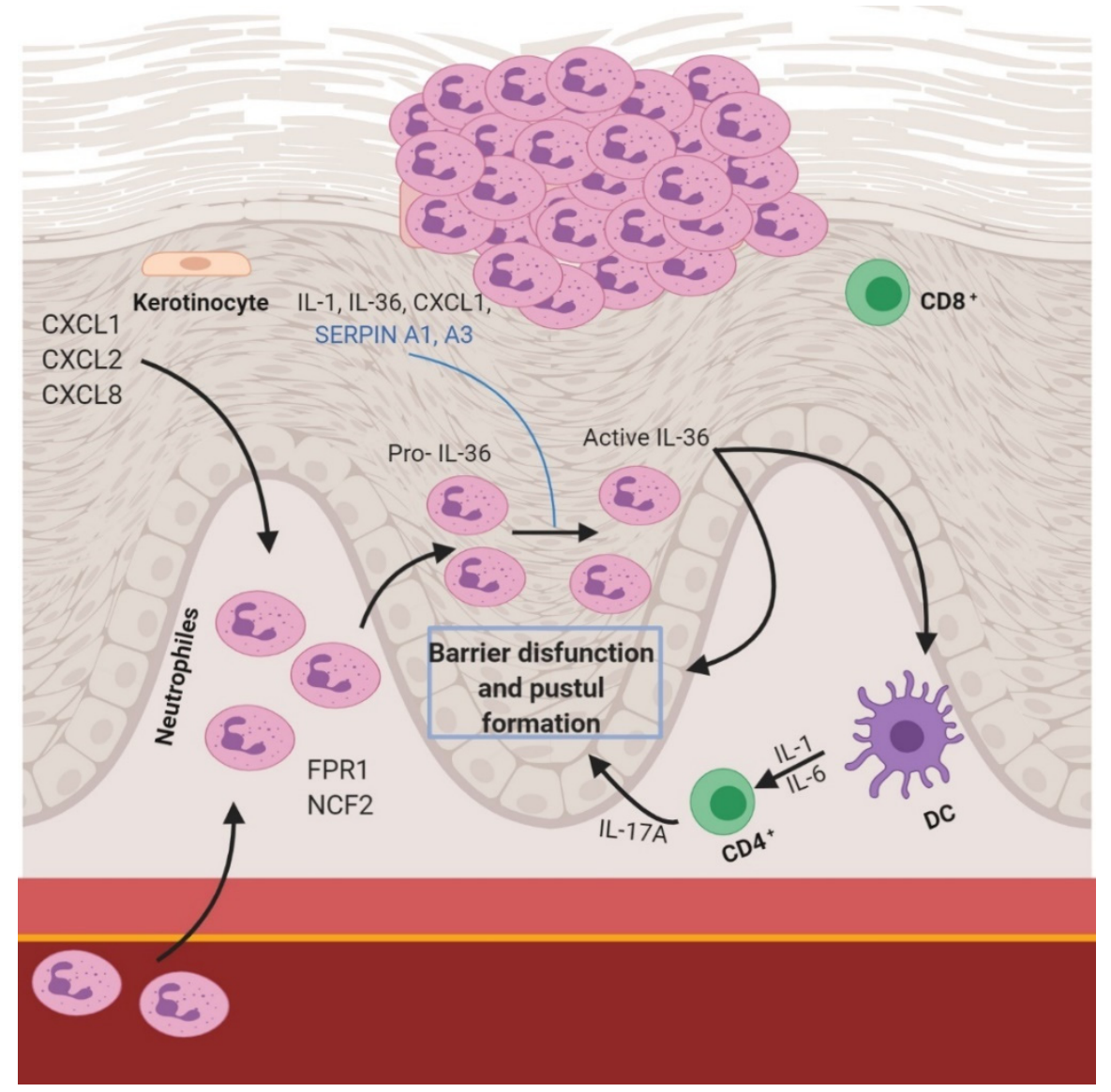

Figure 2. Pathophysiology in pustular psoriasis.

Generalized pustular psoriasis presents with an acute and rapidly progressive course, characterized by diffuse redness and subcorneal pustules, and is often accompanied by systemic symptoms [29]. Another rare type is guttate psoriasis, which is known for its expression by small erythematous plaques and for being mostly common in children and teenagers [30]. There are no data that show any difference in the pathophysiologic mechanism from plaque-type psoriasis. It has been proposed that some streptococcal superantigens stimulate the proliferation of $\mathrm{T}$ cells in the skin in guttate psoriasis [31]. It is known that there is some homology between streptococcal proteins and human IL-17 keratin proteins. There may be an important role played by molecular mimicry in patients with the major histocompatibility HLA-Cw6 allele, since CD8(+) T cell IFN- $\gamma$ responses were elicited by K17 and M6 peptides in said patients [18,32]. One less common type is inverse psoriasis, which is characterized for affecting intertriginous locations and by being more erosive than erythematous plaques of type-plaque. As no data exist showing any difference between the pathophysiologic mechanism of common psoriasis and inverse psoriasis, it seems there is a decrease in the number of CD161+ cells in the plaques of inverse psoriasis. This is speculated to be due to the constant microbial colonization of those areas affected by inverse psoriasis $[33,34]$. Finally, the most severe type, erythrodermic psoriasis, is an acute condition, in which most of the body surface is erythematous and inflamed. There are no data that show any difference in the pathophysiologic mechanism of common psoriasis versus erythrodermic psoriasis [2]. 


\section{Methods}

For the literature research, different databases have been used (SciELO, Springer link, MEDLINE, Embase, LILACS, and PubMed), searching for articles published over the last 10 years. Several trials registered at the US Food and Drug Administration (FDA) and European Medicines Agency (EMA) were also researched. As the keywords, the following terms were used: psoriasis; nanoparticles and psoriasis; microneedles and psoriasis; skin inflammatory diseases; clinical trials and psoriasis; cytokines and psoriasis.

\section{Current Marketed Therapies}

As psoriasis is a chronic disease, long-term therapy is usually necessary. Depending on different factors, such as disease severity or comorbidities, there is a wide range of treatments that have different responses depending on the patient. There are different grades of psoriasis, measured by different factors, such as severity of lesions, percentage of affected surface area, and quality of life [35]. One of the most widely used criteria is the Psoriasis Area and Severity Index (PASI), being the most accurate. The PASI allows comparisons between clinical trials and objectively evaluates the effectiveness of different antipsoriatic drugs.

Following these criteria, there are several grades of psoriasis, from mild to moderate to severe psoriasis. Almost $80 \%$ of psoriasis patients have mild to moderate psoriasis, which can be treated with topical treatments $[36,37]$. In moderate cases, there are some topical treatments, based on corticosteroids, used in combination with other drugs, such as vitamin $\mathrm{D}$, or alone, such as vitamin $\mathrm{D}$ derivatives, vitamin $\mathrm{A}$, and anthralin, which are examples of actual topical treatments.

Vitamin D3 analogues constitute the first line topical treatment for plaque psoriasis and moderately severe scalp psoriasis [38,39]. The beneficial effects of vitamin D induced by exposure to sunlight in the treatment of psoriasis has been known for decades [40-42]. However, vitamin D has shown a relevant yet controversial role in psoriasis, as well as other skin diseases $[43,44]$. In this area, Filoni et al. aimed to shed some light by confirming reduced vitamin $\mathrm{D}$ levels in psoriatic patients and stablishing a relationship between vitamin D levels and psoriasis length [45]. Moreover, Lee et al. also confirmed lower presence of 25-hydroxyvitamin D (25OHD) in psoriasis patients, 25OHD being an possible indicator of the amount of stored Vitamin D [46,47]. However, there is little evidence that the increase in 25OHD after phototherapy correlates with improved disease severity [48].

Moreover, Vitamin D is involved in the proliferation of keratinocytes (Figure 3). In fact, the precursor of vitamin D, 7-DHC, is localized in the keratinocyte membrane, and, by the UVB activation, it is transformed into pre-vitamin D3 or cholecalciferol, which is later converted first to 25OHD by the enzymes CYP27A1 and CYP2R1 and then to 1,25(OH)D or calcitriol, the active form of vitamin D [1,49-52]. Calcitriol regulates differentiation and proliferation of keratinocytes, as well as the balance of the cutaneous immune system and cellular apoptosis. Interestingly, at low vitamin D concentrations, a promotion of keratinocyte differentiation is found, whereas, at high concentrations, an inhibitory effect occurs [43]. Due to the regulation of calcium exerted by vitamin D through calcium receptor induction and phospholipase $C$ enzymes, calcitriol and its analogues (calcitriol, calcipotriol, tacalcitol, hexafluoro-1,25(OH)D, and maxacalcitol) have demonstrated interesting features. In fact, in vitro studies demonstrated that they were able to reduce the psoriatic upregulated levels of S100A7 and regulate cell proliferation in the stratum basale in addition to increasing keratin synthesis and regulating glycoceramides production. Therefore, a decrease in calcitriol or a loss of function of its receptor causes epidermis disruption that results in hyperproliferation of the basal layer [43]. The anti-inflammatory effect attributed to vitamin D may also result from inhibition of production of IL-2, IL-6, and interferon-gamma (IFN- $\gamma$ ). Furthermore, topical calcipotriol inhibits human beta defensin and proinflammatory cytokines, which are increased in psoriatic lesions [43]. Moreover, calcitriol, as well as novel vitamin D3 derivatives, inhibit the transcriptional activity of NFkappaB, a major inducer of inflammation [41]. 
(A)

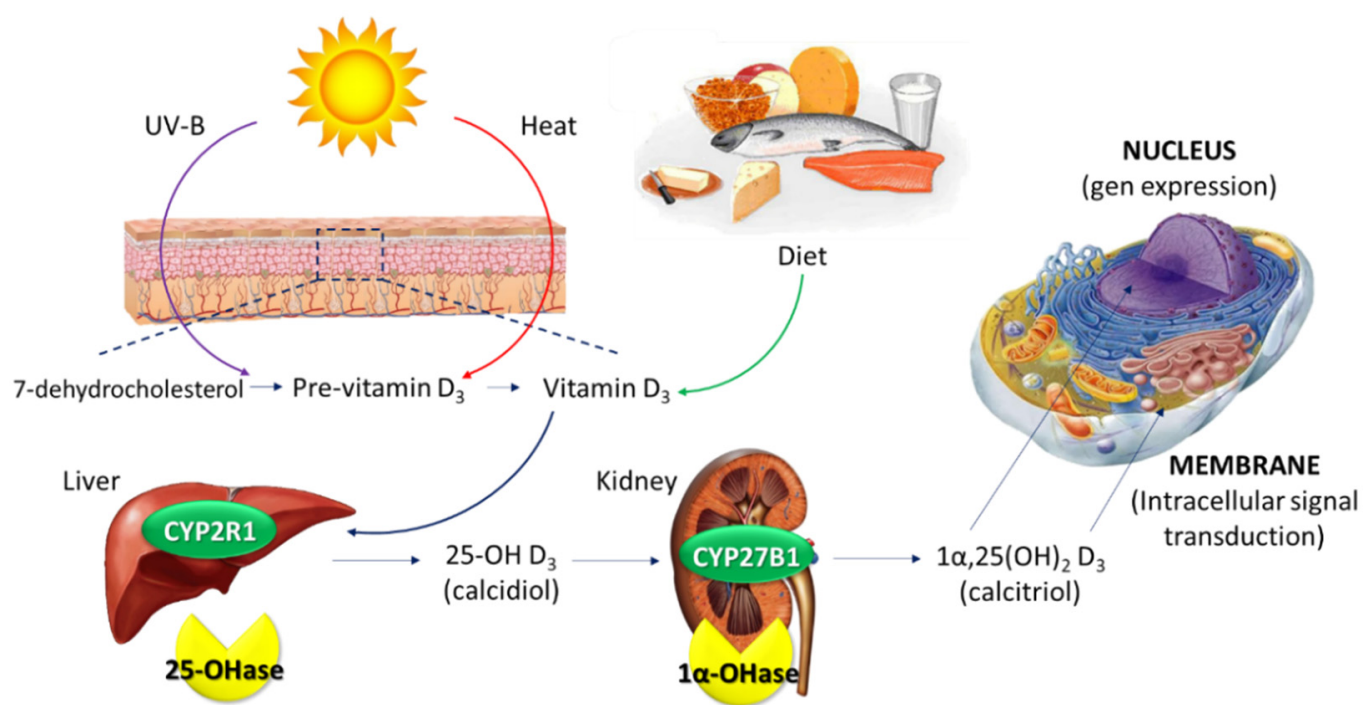

(B)

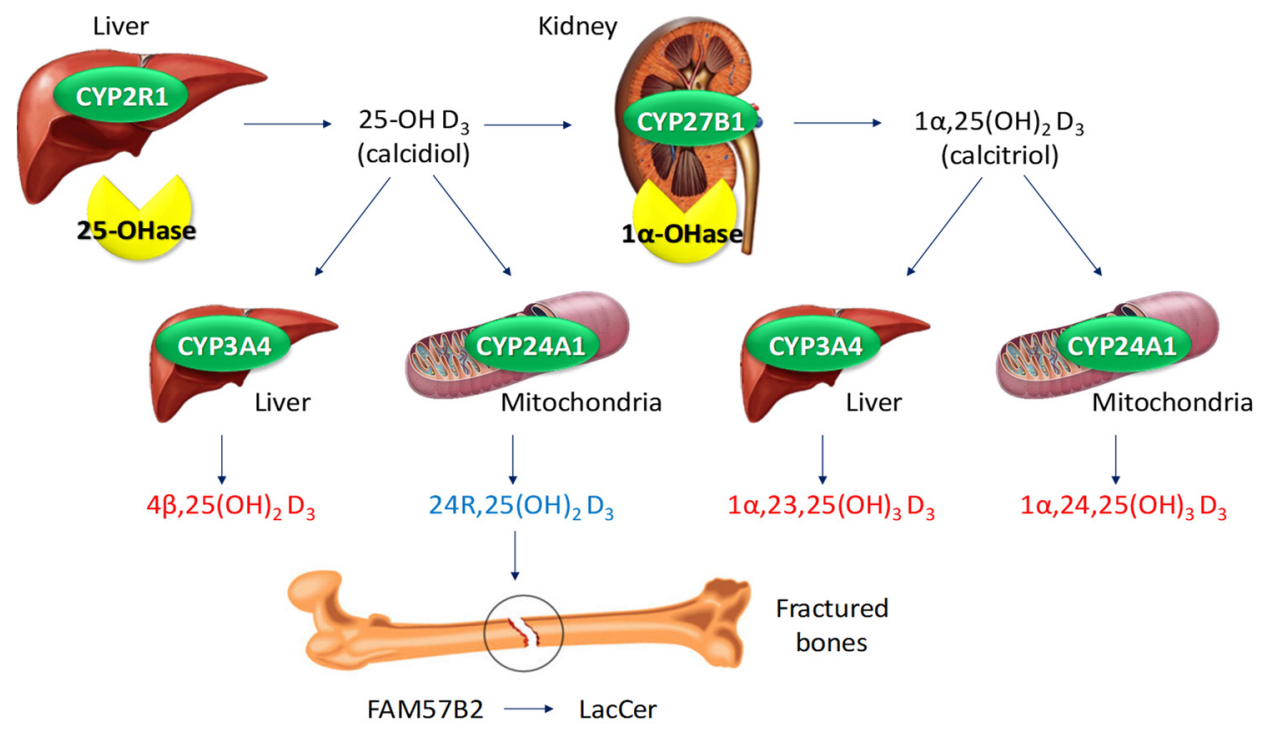

Figure 3. The physiological pathway of vitamin D synthesis and activation. (A) Ultraviolet radiation promotes the conversion of 7-dehydrocholesterol to pre-vitamin $\mathrm{D}_{3}$, which isomerizes to vitamin $\mathrm{D}_{3}$ (also called cholecalciferol) in the skin, due to sun heat. Diet supplements directly provide Vitamin $\mathrm{D}_{3}$, also called ergocalciferol. In the liver, a 25hydroxylation by CYP2R1 is carried out, thus leading to the formation of 25-hydroxyvitamin $\mathrm{D}_{3}$. In the kidney, CYP27B1 further hydroxylates 25 -hydroxyvitamin $\mathrm{D}_{3}$ at the $1-\alpha$ position, resulting in the formation of the active hormone $1 \alpha, 25-$ dihydroxyvitamin $D_{3}$. The active form of vitamin $D$ then enters into the cell via diffusion or endocytic receptor for transcription. Inside the cell, vitamin D binds to both vitamin D receptors at the nucleus and cell membrane. In the nucleus, both active forms of vitamin $\mathrm{D}$ and its receptor form a regulatory complex that finally leads to the beginning of the transcription process. In the cell membrane, binding to vitamin D receptors lead to several intracellular signal transductions. (B) An alternative pathway has been described. In this case, 25-hydroxyvitamin $\mathrm{D}_{3}$ and $1 \alpha, 25$-dihydroxyvitamin $\mathrm{D}_{3}$ metabolites are hydroxylated by other two cytochromes: on the one hand, a dominant gain-of-function mutation in CYP3A4, mainly located in the liver, leads to acceleration in vitamin D inactivation; on the other hand, hydroxylation by CYP24A1, mainly located in the mitochondria, gives rise to the formation of an active metabolite, $24 \mathrm{R}, 25(\mathrm{OH})_{2} \mathrm{D}_{3}$. This molecule has been described to bind to FAM57B2 in fractured bones. This leads to the production of lactosylceramide (LacCer), which is essential for the callus formation and fracture healing.

Interestingly, several studies identified an association between polymorphisms of vitamin D receptor (VDR) and psoriasis susceptibility [43]. However, this is still controversial $[53,54]$. The mechanism of vitamin D is mediated by the vitamin D receptor (VDR), 
and after its activation, it interacts with retinoid $X$ receptor ( $R X R)$ to form a heterodimeric complex. The VDR-RXR complex is recruited to the vitamin D response elements (VDREs) in the promoter of target genes to regulate their expression. This process is described as the genomic action of vitamin $\mathrm{D}$ in contrast to the nongenomic action, which is the direct effect that vitamin $\mathrm{D}$ has on the previously mentioned signalling pathways [38]. Allelic variations in individual VDR genes may determine a different response to treatment: the isoform A of VDR is associated with a greater therapeutic response in psoriatic patients [43]. In this sense, VDR ligands inhibit the expression of pro-inflammatory cytokines produced by $\mathrm{T}$ lymphocytes, which are responsible for the exacerbation of the skin inflammation. Apart from that, $1 \alpha, 25(\mathrm{OH}) 2 \mathrm{D} 3$ enhances expression of IL-10 within the psoriatic lesions. Moreover, biological activity of vitamin D3 analogues leads to suppression of the T cellmediated immune response [41]. In addition, there is evidence that one active form of vitamin D3 synthetized by CYP11A1, 20(OH)D3, has anti-proliferative, pro-differentiation, and anti-inflammatory effects on cultured skin cells, comparable to or better than those of 25OHD. Thus, it has been proposed as a new candidate for primary or adjuvant therapy of hyperproliferative or inflammatory disorders, such as psoriasis [55].

As it has been mentioned, apart from the classical activation route for vitamin D, alternative routes have been described, such as the CYP11A1 route, which leads to hydroxy metabolites. The traditional role of CYP11A1 was associated to initial steroid synthesis, solely in steroidogenic organs using cholesterol as the substrate [55]. This involved hydroxylations at C22 and C20, followed by oxidative cleavage of the bond between C20 and C22 to produce pregnenolone, a precursor to all steroids [55]. However, it has now been documented that alternative substrates from cholesterol have been identified, such as 7DHC, vitamins D2 and D3, ergosterol, and lumisterol [56]. It has been dilucidated that CYP11A1 initiates the metabolism of vitamin D: from $\mathrm{D} 3$ to $(\mathrm{OH}) \mathrm{nD} 3$ [56]. The main metabolite resulting from a single hydroxylation of D3 by CYP11A1 is $20(\mathrm{OH}) \mathrm{D} 3$, but 22(OH)D3 and 17(OH)D3 are also produced [57]. The major dihydroxy and trihydroxy metabolites formed from CYP11A1 hydroxylation of 20OHD3 include 20,23(OH)2D3, 20,22(OH)2D3, 17,20(OH)2D3, and 17,20,23(OH)3D3 [57]. Moreover, further hydroxylation of CYP11A1-derived metabolites can occur by CYP27B1, CYP24A1, and CYP27A1 [58].

Apart from the well-known mechanism by binding $1 \alpha, 25(\mathrm{OH}) 2 \mathrm{D} 3$ with VDR, there are different nongenomic associated sites. VDR has an alternative form binding-A-pocket, which leads to rapid nongenomic responses at the cell membrane level [55]. Furthermore, there is a rapid steroid binding protein disulphide-isomerase A3 (PDIA3), which has been identified as an alternative membrane-bound receptor. PDIA3 activates phospholipase $\mathrm{C}$ in a $\mathrm{G}$ protein-coupled process and results in the production of inositol trisphosphate (IP3) and diacylglycerol. These two cellular messengers mediate the rapid release of calcium from the cellular stores [59]. Recently, $\operatorname{ROR} \gamma$, another nuclear receptor, has been identified as a target for vitamin D, where D3 hydroxyderivatives could act as antagonists, regulating some phenotypic expressions with affectation in several immune functions, metabolism, and cerebellar development [59]. Recently, Vitamin D has been studied outside the immune system, with some VDRs localised in the intestinal barrier, regulating intestinal inflammation, autophagy, or gut microbiota [60].

In severe cases, a systemic treatment, sometimes combined with local treatment, is necessary due to the increased extension of the affected surface. Some strategies for enhancing the therapeutic results of the topical treatments, such as using some adjunct agents, such as penetrating or permeating enhancers, or phototherapy, can be employed [61]. It has been demonstrated that monotherapies, which require irregular applications, are not the best options for the optimisation of the treatment adherence [62]. One option for improving the treatment adherence is a combination regime [63], which allows applications in a fixed dose with a low frequency of application [64].

Topical therapies are the backbone of management of psoriasis. They are safe and well-tolerated by the patients. Currently, vitamin D derivatives are used in combination with betamethasone for mild plaque-type psoriasis cases. Moreover, topical calcineurin 
inhibitors (TCIs) and Vitamin D analogues are the treatment of choice among the various topical agents available for different subtypes of psoriasis. For example, TCIs can be used as steroid-sparing agents on the face and intertriginous areas in inverse psoriasis [65]. Tazarotene can be used as an effective maintenance therapy (Table 1). New vehicle formulations, such as gels, lotions, solutions, shampoos, foams, etc., have been developed to improve physicochemical properties, such as lack of adherence, penetration rates, or different pharmacological forms, depending on the application site, thus improving the patient compliance, which is of utmost importance for optimum results. Target-based topical agents are being developed and tested. Moreover, advancement in nanotechnology has led to the possibility of improving the efficacy of topical agents through targeting, improving adherence of pharmaceutical dosage forms and/or drug penetration rates, and minimizing side effects. The formulation of newer molecules and newer drug delivery systems will significantly expand the therapeutic stock for the treatment of psoriasis. As long as there is a general consensus about using topical therapy for mild to moderate psoriasis, there are not a great number of studies about the long-term use of these medicines.

There is a wide range of treatments for severe psoriasis, from topical gels to systemic oral drugs. There are some different types, with different targets, having a wide range of effectiveness and safety. On the one hand, there are the oldest class-level treatments [66], such as acitretin, ciclosporin, fumaric acid, esters, and methotrexate. On the other hand, there are the biologics: anti-TNF alpha treatments, such as etanercept, infliximab, adalimumab, and certolizumab. All of these systemic drugs have been approved for their use in psoriasis treatment. It has been demonstrated by different studies that biologics outperform the small molecules to reach PASI 90 (Table 2).

Table 1. Accepted topical treatments for psoriasis.

\begin{tabular}{|c|c|c|c|}
\hline Active Ingredient & Effects & Drawbacks & References \\
\hline Moisturizers & $\begin{array}{l}\text { Reduces hyperproliferation, differentiation, } \\
\text { and apoptosis. Moreover, anti-inflammatory } \\
\text { effects and improving barrier function. }\end{array}$ & $\begin{array}{l}\text { Irritant dermatitis, allergic contact dermatitis, } \\
\text { fragrance allergy, stinging, and acne. }\end{array}$ & {$[67,68]$} \\
\hline Coal Tar & $\begin{array}{l}\text { Suppresses DNA synthesis, reducing the } \\
\text { hyperproliferation of keratinocytes. }\end{array}$ & $\begin{array}{l}\text { Odour, staining, irritant contact } \\
\text { dermatitis, erythema, stinging, folliculitis, } \\
\text { and formation of keratoacanthomas. }\end{array}$ & [69] \\
\hline Salicylic acid & $\begin{array}{l}\text { Reduces intercellular cohesiveness of the } \\
\text { horny cells by dissolving the intercellular } \\
\text { cement material. Furthermore, it reduces } \\
\text { the pH of the stratum corneum, } \\
\text { increasing hydration and softening. }\end{array}$ & $\begin{array}{c}\text { Potential chronic or acute systemic } \\
\text { intoxication, oral mucosa burning, frontal } \\
\text { headache, central nervous system symptoms, } \\
\text { metabolic acidosis, tinnitus, nausea, and } \\
\text { vomiting. }\end{array}$ & {$[70]$} \\
\hline $\begin{array}{c}\text { Topical } \\
\text { calcineurin } \\
\text { inhibitors (TCIs) }\end{array}$ & $\begin{array}{l}\text { It inhibits the action of calcineurin } \\
\text { phosphatase and block the production of } \\
\text { inflammatory substances that are thought to } \\
\text { be important in causing skin lesions. }\end{array}$ & Stinging sensation and skin irritation. & [71] \\
\hline Tazarotene & $\begin{array}{l}\text { It binds to } \beta \text { and } \gamma \text { retinoic acid on the cell } \\
\text { membrane of keratinocytes and is then } \\
\text { transported to the nucleus, altering } \\
\text { transcription of genes in keratinocytes. }\end{array}$ & $\begin{array}{l}\text { The most common side effect of tazarotene is } \\
\text { localized irritation. }\end{array}$ & {$[72,73]$} \\
\hline $\begin{array}{l}\text { Anthralin } \\
\text { (Dithranol) }\end{array}$ & $\begin{array}{l}\text { It reduces keratinocyte proliferation, } \\
\text { prevents T-cell activation, and restores cell } \\
\text { differentiation, probably through } \\
\text { mitochondrial dysfunction. }\end{array}$ & $\begin{array}{l}\text { Skin irritation, stains lesioned, and adjoining } \\
\text { skin, hair, nails, clothing, and other objects, } \\
\text { with which the patients come into contact. }\end{array}$ & [74] \\
\hline
\end{tabular}


Table 1. Cont.

\begin{tabular}{|c|c|c|c|}
\hline Active Ingredient & Effects & Drawbacks & References \\
\hline $\begin{array}{c}\text { Topical } \\
\text { corticosteroids }\end{array}$ & $\begin{array}{l}\text { Corticosteroids are vasoconstrictive, } \\
\text { antiproliferative, anti-inflammatory, and } \\
\text { immunosuppressive. They bind to the } \\
\text { intracellular corticosteroid receptor and } \\
\text { regulate gene transcription of numerous } \\
\text { genes, particularly those that code for } \\
\text { proinflammatory cytokines. }\end{array}$ & $\begin{array}{l}\text { Skin atrophy striae, telangiectasia, or } \\
\text { secondary infection. Therefore, potent TCS } \\
\text { should not be used on the face or } \\
\text { intertriginous sites. Systemic adverse events } \\
\text { occur when TCS is used for prolonged } \\
\text { periods of time or at doses higher than } \\
\text { commonly prescribed. Prolonged use of } \\
\text { potent TCS may result in its significant } \\
\text { systemic absorption, which can lead to HPA } \\
\text { axis suppression, Cushing's syndrome, and } \\
\text { hyperglycaemia. }\end{array}$ & {$[36,75]$} \\
\hline $\begin{array}{l}\text { Vitamin D } \\
\text { analogues }\end{array}$ & $\begin{array}{l}\text { Vitamin D analogues bind to the intracellular } \\
\text { Vitamin D receptor, which then binds to and } \\
\text { regulates the genes involved in epidermal } \\
\text { proliferation, inflammation, and } \\
\text { keratinization. }\end{array}$ & $\begin{array}{c}\text { Skin irritation, hypercalcemia, hypercalciuria, } \\
\text { and parathyroid hormone suppression, but } \\
\text { these are very rare. }\end{array}$ & [76] \\
\hline
\end{tabular}

Table 2. Accepted systemic treatments.

\begin{tabular}{|c|c|c|c|c|}
\hline $\begin{array}{c}\text { Type of } \\
\text { Treatment }\end{array}$ & Drug & Effects & Drawbacks & References \\
\hline \multirow{4}{*}{$\begin{array}{l}\text { Conventional } \\
\text { treatments }\end{array}$} & Acitretin & $\begin{array}{l}\text { It binds to nuclear receptors on genes } \\
\text { controlling cellular differentiation, } \\
\text { anti-proliferation, anti-inflammation, } \\
\text { anti-keratinization, and inhibition of } \\
\text { neutrophil chemotaxis. It is the only systemic } \\
\text { treatment that is not immunosuppressive. }\end{array}$ & $\begin{array}{c}\text { Depression, } \\
\text { hypertriglyceridemia and } \\
\text { hypercholesterolemia, } \\
\text { Myalgias, cheilitis, skin } \\
\text { peeling, alopecia, xerosis, } \\
\text { rhinitis, nail dystrophy, } \\
\text { epistaxis, sticky skin, retinoid } \\
\text { dermatitis, and xerophthalmia. }\end{array}$ & [77] \\
\hline & $\begin{array}{l}\text { Fumaric Acid } \\
\text { Esthers (FAEs) }\end{array}$ & $\begin{array}{l}\text { It has immunomodulatory, anti-inflammatory, } \\
\text { and antiproliferative properties and apoptotic } \\
\text { actions on activated T cells. }\end{array}$ & $\begin{array}{l}\text { Warmth, reddening of the face, } \\
\text { and headaches, proteinuria, } \\
\text { reversible renal insufficiency, } \\
\text { microscopic haematuria, and } \\
\text { proximal tubular damage. }\end{array}$ & [78] \\
\hline & Cyclosporine & $\begin{array}{l}\text { It inhibits Interleukin synthesis, such as IL-2 } \\
\text { and T cell differentiation. }\end{array}$ & $\begin{array}{l}\text { Hypertension, arrythmia, } \\
\text { hypertension, anxiety, } \\
\text { headaches, fever, } \\
\text { hypomagnesemia, } \\
\text { hyperkalaemia, dyslipidaemia, } \\
\text { and encephalopathy. }\end{array}$ & [79] \\
\hline & Methotrexate & $\begin{array}{l}\text { It reduces interleukin (IL)-17 mRNA and } \\
\text { IL-17 protein expression in CD3- and } \\
\text { CD28-stimulated peripheral blood } \\
\text { mononuclear cells. It modulates } \\
\text { pro-inflammatory mediators and its effects on } \\
\text { atherogenic gene expression in psoriatic } \\
\text { lesion skin. }\end{array}$ & $\begin{array}{l}\text { Nausea, stomach pain, and } \\
\text { diarrhoea. }\end{array}$ & [80] \\
\hline $\begin{array}{l}\text { Small } \\
\text { molecules }\end{array}$ & Apremilast & $\begin{array}{l}\text { It inhibits the expression and/or } \\
\text { production of TNF- } \alpha \text {, IFN- c, IL-12, and IL-23 } \\
\text { and the chemokines CXCL9, CXCL10, CCL2, } \\
\text { and CCL3, IL-2, IL-5, IL-13, IL-17, TNF- } \alpha \text {, and } \\
\text { IFN-c by stimulated T cells and IFN-a by } \\
\text { dendritic cells. }\end{array}$ & $\begin{array}{c}\text { Nausea, diarrhoea, and } \\
\text { headaches. }\end{array}$ & [81] \\
\hline $\begin{array}{l}\text { Small } \\
\text { molecules }\end{array}$ & Tofacitinib & $\begin{array}{l}\text { It is a potent inhibitor of JAK } 1 \text { and JAK } 3 \text { and } \\
\text { has some activity against JAK } 2 \text { and Tyk } 2 \text {. }\end{array}$ & $\begin{array}{l}\text { Nasopharyngitis, upper } \\
\text { respiratory tract infection, } \\
\text { headache, urinary tract } \\
\text { infection, and diarrhoea. }\end{array}$ & [82] \\
\hline
\end{tabular}


Table 2. Cont.

\begin{tabular}{|c|c|c|c|c|}
\hline $\begin{array}{l}\text { Type of } \\
\text { Treatment }\end{array}$ & Drug & Effects & Drawbacks & References \\
\hline \multirow{4}{*}{$\begin{array}{l}\text { Anti-TNF } \\
\text { alpha }\end{array}$} & Infliximab & $\begin{array}{l}\text { It interferes with the actions of TNF- } \alpha \\
\text { by directly binding to soluble and } \\
\text { transmembrane TNF- } \alpha \text { molecules in the } \\
\text { plasma and the diseased tissue. }\end{array}$ & $\begin{array}{l}\text { Dyspnoea, urticaria, } \\
\text { hypotension, flushing, and } \\
\text { headache. }\end{array}$ & [83] \\
\hline & Etanercept & $\begin{array}{l}\text { It is a recombinant human TNF-recipient by } \\
\text { subcutaneous injection. } \\
\text { Tor fusion protein that antagonizes the effects } \\
\text { of endogenous TNF by competitively } \\
\text { inhibiting its in- } \\
\text { study disintegration with cell-surface } \\
\text { receptors. }\end{array}$ & $\begin{array}{l}\text { Respiratory infections, flu-like } \\
\text { symptoms, and } \\
\text { gastrointestinal symptoms. }\end{array}$ & {$[84,85]$} \\
\hline & Adalimumab & $\begin{array}{l}\text { It blocks its interaction with the p55 and p75 } \\
\text { cell surface TNF receptors. }\end{array}$ & $\begin{array}{l}\text { Headache, nausea, elevated } \\
\text { triglycerides, cough, sinus } \\
\text { congestion, and fatigue most } \\
\text { common. }\end{array}$ & [86] \\
\hline & Certolizumab & $\begin{array}{c}\text { It inhibits lipopolysaccharide-induced IL-1- } \beta \\
\text { release from monocytes and provokes } \\
\text { nonapoptotic cell death in tmTNF- } \\
\alpha \text {-expressing cells. }\end{array}$ & $\begin{array}{l}\text { Headache, nasopharyngitis, } \\
\text { upper respiratory tract } \\
\text { infections, diarrhoea, and } \\
\text { sinusitis. }\end{array}$ & {$[87,88]$} \\
\hline Anti-IL12/23 & Ustekinumab & $\begin{array}{l}\text { It is a human monoclonal antibody that binds } \\
\text { to the shared p } 40 \text { protein subunit of human } \\
\text { interleukins } 12 \text { and } 23 \text { with high affinity and } \\
\text { specificity (unpublished data), thereby } \\
\text { preventing interaction with their cell surface } \\
\text { IL12R } \beta 1 \text { receptor. }\end{array}$ & $\begin{array}{l}\text { Headache, nasopharyngitis, } \\
\text { arthralgia, and upper } \\
\text { respiratory tract system. }\end{array}$ & [89] \\
\hline \multirow{3}{*}{ Anti-IL17 } & Secukinumab & $\begin{array}{c}\text { It is a recombinant, high-affinity, fully human } \\
\text { immunoglobulin G1k monoclonal antibody } \\
\text { that selectively binds and neutralizes } \\
\text { interleukin-17A. }\end{array}$ & $\begin{array}{l}\text { Nasopharyngitis, headache, } \\
\text { and upper respiratory tract } \\
\text { infection. }\end{array}$ & [90] \\
\hline & Bimekizumab & $\begin{array}{l}\text { It is a monoclonal antibody of the } \\
\text { immunoglobulin G1 isotype, rationally } \\
\text { designed to be able to bind at a similar site on } \\
\text { both IL-17A and IL-17F, conveying dual } \\
\text { inhibition of both isoforms. }\end{array}$ & $\begin{array}{l}\text { Nasopharyngitis, } \\
\text { oropharyngeal pain, and } \\
\text { headache. }\end{array}$ & [91] \\
\hline & Ixekizumab & $\begin{array}{l}\text { It is recombinant, high-affinity, humanized } \\
\text { IgG4-k monoclonal antibody, which } \\
\text { selectively binds and neutralizes interleukin } \\
\text { 17A (IL-17A), the proinflammatory and } \\
\text { primary effector cytokine of type } 17 \text { helper T } \\
\text { (Th17) cells. }\end{array}$ & $\begin{array}{l}\text { Nasopharyngitis, upper } \\
\text { respiratory infection, } \\
\text { injection-site reaction, and } \\
\text { headache. }\end{array}$ & {$[92,93]$} \\
\hline $\begin{array}{c}\text { IL17 R } \\
\text { antagonist }\end{array}$ & Brodalumab & $\begin{array}{l}\text { It binds with high affinity to human } \\
\text { interleukin-17RA and blocks the biologic } \\
\text { activity of interleukins 17A, 17F, 17A/F } \\
\text { heterodimer, and 17E (interleukin-25). }\end{array}$ & $\begin{array}{l}\text { Nasopharyngitis, upper } \\
\text { respiratory tract infection, } \\
\text { arthralgia, and erythema at the } \\
\text { injection site. }\end{array}$ & [94] \\
\hline \multirow{4}{*}{ Anti-IL23 } & Tildrakizumab & $\begin{array}{c}\text { It is a novel, high-affinity humanized IgG1/j } \\
\text { monoclonal antibody that specifically binds } \\
\text { to the p19 subunit of human IL-23 without } \\
\text { binding IL-12. }\end{array}$ & $\begin{array}{l}\text { Nasopharyngitis and } \\
\text { headache. }\end{array}$ & [95] \\
\hline & Guselkumab & $\begin{array}{l}\text { It is a fully human IgG1 lambda monoclonal } \\
\text { antibody that binds to the p19 subunit of } \\
\text { IL-23. }\end{array}$ & $\begin{array}{l}\text { Nasopharyngitis and upper } \\
\text { respiratory tract infection. }\end{array}$ & {$[96,97]$} \\
\hline & Risankizumab & $\begin{array}{l}\text { It is a humanised IgG1 monoclonal anti- body } \\
\text { that binds the p19 subunit of IL-23, thus } \\
\text { inhibiting this key cytokine and its role in } \\
\text { psoriatic inflammation. }\end{array}$ & $\begin{array}{l}\text { Upper respiratory tract } \\
\text { infection, urinary tract } \\
\text { infection, influenza, and } \\
\text { headache. }\end{array}$ & [98] \\
\hline & Mirikizumab & $\begin{array}{l}\text { It is a humanized IgG4-variant monoclonal } \\
\text { antibody that binds to the p19 subunit of } \\
\text { IL-23 and does not bind IL-12. }\end{array}$ & $\begin{array}{l}\text { Viral upper and other } \\
\text { respiratory tract infections, } \\
\text { injection-site pain, } \\
\text { hypertension, and diarrhoea. }\end{array}$ & [99] \\
\hline
\end{tabular}


Despite advances in the effectiveness of this different systemic treatments, they do not work in all patients, showing problems associated with thereproducibility of results. It seems that low absorption of treatments and the possible toxicity of the drugs are common and there are relevant drawbacks to guaranteeing an effective treatment. Thus, there are still investigations finding different drugs and biosimilar agents for new treatments [100]. Furthermore, there is an increasing interest in the study of different administration routes and new carriers for these drugs, such as microneedles or the use of nanotechnology.

\section{Clinical Trials}

Research in new pharmacological approaches for psoriasis has been intensely carried out during the last decade. In recent years, many breakthroughs in biological treatments and new small molecules have been developed. Furthermore, there are different drugs that are under clinical trials. From topical application to oral administration, there are cutting edge drugs that have been used to improve actual pharmacological arsenal for psoriasis. There are some new drugs in different types of administration are still in clinical trials at the date of this review but might be approved in the coming months (Table 3).

Table 3. Cutting edge treatments for psoriasis under clinical trials.

\begin{tabular}{|c|c|c|c|c|}
\hline Clinical Trial Phase & Drug Name & Administration Via & Targeting & References \\
\hline \multirow{5}{*}{ Phase 1} & BOS-475 & Topical & $\begin{array}{l}\text { Bromodomain and extraterminal } \\
\text { domain protein inhibitors }\end{array}$ & [101] \\
\hline & ABBV-157 & Oral & ROR $\gamma$ t inhibitor & [102] \\
\hline & CC-92252 & Oral & $\begin{array}{c}\text { Interleukin-2 receptor agonists; } \\
\text { Regulatory T-lymphocyte } \\
\text { stimulants }\end{array}$ & [103] \\
\hline & EDP 1066 & Oral & Immunomodulators & [104] \\
\hline & EDP 1815 & Oral & Immunomodulator & [105] \\
\hline \multirow{7}{*}{ Phase II } & ABY-035 & Parenteral & IL-17A inhibitor & [106] \\
\hline & ARQ-151 & Topical & PDE4 Enzyme inhibitor & [107] \\
\hline & BI 730357 & Oral & Nuclear receptor antagonist & [108] \\
\hline & EISO (SAN021) & Topical & PDE4 blocker & [109] \\
\hline & JTE-451 & Oral & ROR inhibitor & [110] \\
\hline & M1095 & Parenteral & $\begin{array}{l}\text { Trivalent monomeric nanobody } \\
\text { that neutralizes interleukins } \\
\text { IL-17A, IL-17F, and IL-17A/F }\end{array}$ & [111] \\
\hline & PF-06700841 & Topical & JAK1 and TYK2 inhibitor & [112] \\
\hline \multirow{2}{*}{ Phase II } & PF-06826647 & Oral & TYK2 inhibitor & [113] \\
\hline & SHR-1314 & Parenteral & IL-17A Antagonist & [114] \\
\hline \multirow{11}{*}{ Phase III } & BMS- 986165 & Oral & Tyk2 inhibitor & [115] \\
\hline & BCD-085 & Parenteral & IL-17 inhibitor & [116] \\
\hline & BI695502 & Parenteral & TNF- $\alpha$ inhibitor & [117] \\
\hline & CF101 & Oral & Adosine A3 receptor inhibitor & [118] \\
\hline & CHS-1420 & Parenteral & TNF- $\alpha$ inhibitor & [119] \\
\hline & Filgotinib & Oral & JAK 1 inhibitor & [120] \\
\hline & Mirikizumab & Parenteral & IL-23 inhibitor & [121] \\
\hline & Serlopitant & Oral & Neurokinin-1 receptor antagonist & [122] \\
\hline & Tapinarof & Topical & AHR agonist & [123] \\
\hline & Tikdrakizumab & Parenteral & IL-23 inhibitor & [124] \\
\hline & Upadacitinib & Oral & JAK inhibitor & [125] \\
\hline
\end{tabular}

Topical application is the main administration route for psoriasis-targeted drugs. As has been specified before, topical formulations are the backbone of the treatments for 
psoriasis, especially in moderate and mild cases. This is why there is important interest on the development of new formulations or new active drugs that could improve the performance of existing treatments. In fact, there are many drugs in topical formulations under clinical trials. Parenteral administration has led to different approaches in psoriasis. Despite the fact that the majority of biological treatments released in recent years have been formulated as subcutaneous medications, oral administration is the most explored in the current clinical trials.

\section{Nanotechnological Approaches for Psoriasis}

In the past 20 years, there has been a revolution in different fields related to the use of nanotechnology. There has been an intense study of nanoparticles for the design and manufacturing of new treatments in medicine. Thanks to the versatility of this technology, it is possible to use a wide range of materials with completely different properties in different functions [126]. Nanoparticles are mainly used as carriers for chemotherapeutic active drugs. Therefore, biodegradable nanoparticles constitute one of the most relevant approaches for the present and future treatment of psoriasis.

\subsection{Polymeric Nanoparticles (PNPS)}

PNPs are used as biomaterials due its characteristics, such as good biocompatibility, wide range of sizes and structures, bioimitative characteristics, and simple elaboration. It is possible to derivatize their structure on many paths, permitting good targeting as a drug delivery system. There are many types of polymer-based nanoparticles-the main types are nanospheres and nanocapsules - but there are many others, such as dendrimers and micelles.

\subsubsection{Nanospheres}

Nanospheres are based on the homogeneous dispersion of the drug inside their polymer matrix structure [121]. The main objectives of nanospheres, which could be biodegradable or non-biodegradable depending on the materials employed on their manufacturing, are to enhance solubility, improve absorption, and control drug release.

Batheja et al. prepared tyrosine-derived nanospheres (tyrospheres), loaded in a gel, obtaining significant results, demonstrating an improving absorption in studies in vitro and in vivo [127]. In this study, there was a comparative difference between different gels for supporting the nanoparticles. The gel type had a significant effect on the nanosphere dispersion: nanospheres were more homogeneously dispersed in the METHOCEL ${ }^{\mathrm{TM}} \mathrm{K} 15 \mathrm{M} 0$ (HPMC) than in Carbopol. Three concentrations (3, 6, and $10 \mathrm{mg} / \mathrm{mL}$ ) of NSP dispersions in HPMC were tested, with $3 \mathrm{mg} / \mathrm{mL}$ resulting in the most homogeneous dispersion of individual particles with $\sim 40 \mathrm{~nm}$ in diameter, which is similar to the previously reported size in bibliography. Moreover, the use of tyrospheres as a cargo system for the delivery of Vitamin D3 treatment has been studied by Diering et al., obtaining different particle sizes from 64.3 to $73.4 \mathrm{~nm}$, depending on the concentration of Vitamin D3 [128]. Their conclusions evidence that there was an enhanced absorption of the treatment, having an increasing concentration of the drug compared to the control.

\subsubsection{Nanocapsules}

Nanocapsules are nanoparticles, with a structure based on the encapsulation of the drug in the core of the nanostructure, protected by the polymer shield [121]. Its core can consist of an oily phase or a polymer matrix, where the drug is dissolved, or the drug can be in its molecular form, distributed homogeneously in the nanoparticle. The main advantages offered by nanocapsules include sustained release, incremental drug selectivity, and improvement of drug bioavailability and alleviation of drug toxicity $[129,130]$.

In this context, Marchiori et al. worked in dexamethasone-charged nanocapsules for drug delivery through topical administration [131]. The composition of nanocapsules consisted of an oily phase in the core of capric triglyceride mixture and a shield of poly- 
caprolactone in a Carbopol gel, obtaining a particle size of $201 \mathrm{~nm}$ with an encapsulation rate of $>95 \%$. Its study in vitro demonstrated a controlled release of the drug with a good stability, suggesting further studies in vivo in the near future.

\subsubsection{Dendrimers}

Dendrimers are a type of nanoparticle, characterised by being spherical, monodisperse and multivalent macromolecules. Their structure allows some unique features, such as their good solubility, biocompatibility, and a good reactivity ratio [132]. Moreover, depending on which structure is designed, the drug delivered could be encapsulated or as a covalently conjugated drug form, preventing any chemical or biological degradation. In addition, their structure permits the use of different drug release mechanisms [133].

Agrawal et al. studied the ability of polypropylene imine dendrimers to transport dithranol for topical treatment [134]. Its formulation obtained a particle size of $8 \mathrm{~nm}$, with the drug loaded in the dendrimers after an exposure of dendrimers to dithranol. There was a significant improvement in drug permeation, from $35 \%$ to $95 \%$ of drug penetration, and a decrease in skin irritation, compared to a solution of dithranol. Conclusively, dendrimers should be studied as possible candidates in drug delivery systems in the future.

\subsubsection{Micelles}

Micelles are nanocarriers that are constituted by amphiphiles, having a concentration above critical micelle concentration, providing a core corona structure. Due to its composition, micelles are good protectors for aquaphobic drugs, which are b protected inside the micelle and surrounded by a hydrophobic barrier [135]. Meanwhile, in the external face, there is a hydrophilic barrier, allowing the micelle to be solubilized in aqueous media. This structure permits an elongation of the drug circulation life, increasing the permeation and absorption of the drug. Micelles have many advantages, such as high drug loading, increased bioavailability, low degradation of drugs, and decreased side effects. All its characteristics make micelles good candidates for topical treatments in skin diseases, such as psoriasis. In this context, Lapteva et al. studied MPEG-dihex PLA as a delivery system for tacrolimus, in which micelles diameters were below $50 \mathrm{~nm}$ [136]. This study was encouraged by the fact that tacrolimus is not soluble in water, being a good candidate for an improvement of solubility, bioavailability, and permeability. In the in vivo studies, micelles remained on the skin surface, unable to pass to the stratum corneum but remaining in the follicular ducts. Conclusively, micelles were not able to enhance permeation through the skin, which makes them less effective than other drug delivery systems.

\subsection{Lipid-Based Nanoparticles}

Lipid nanoparticles are produced with physiological lipids, which provide safety and non-toxicity from the structure of the nanoparticles [137,138]. Due to its structure, lipid nanoparticles have several advantages, such as an enhanced stability of the drug, thus a longer lifetime in circulation, biodegradability, targeting, and good drug load, with very competitive costs.

\subsubsection{Liposomes}

Liposomes are closed vesicles, produced by one or more lipid layers overlapped from the core to the surface, having the same number of aqueous compartments between layers $[137,139]$. Liposomes are one of the most studied lipid-based nanoparticles in the treatment of dermatological disorders due to their unique features of being able to act like organic solvents to solubilise non-soluble drugs, getting in groups acting as local depots for a control releasing of the drug, enhancing penetration and diffusion of molecules with low solubility into the lipid covering of the stratum corneous [139]. Additionally, liposome physicochemical characteristics are easily controlled by their composition. Features, such as charge, size, permeability, or durability, are malleable by researchers, giving different approaches for the same treatments. 
Wadhwa et al. studied the use of a loaded liposome of fusidic acid for a proficient treatment of plaque psoriasis [140]. These liposomes where prepared, obtaining a range in different physicochemical characteristics depending on the concentration parameters, such as size, ranging from 572.7 to $740.1 \mathrm{~nm}$, or entrapment efficiency, ranging from $52.1 \%$ to $72.6 \%$. This study showed that the formulations were stable and had an enhancing effect on the efficacy of the anti-psoriatic drug compared with a conventional preparation in in vivo studies in mouse tail models. In this sense, liposomes are effective for their use in a drug delivery system in skin disorders, such psoriasis.

\subsubsection{Lipospheres}

Lipospheres are lipid-based nanoparticles, which are produced by a stabilization of an aquaphobic core by coating phospholipid molecules on its surface. This structure provides some features to lipospheres that could not be compared with other lipid-based nanoparticles, such as its low costs, an increased stability, easy production, controlled release rate, and a good dispersion rate in aqueous media [141]. Lipospheres have been used in different administration routes, such as oral, intravenous, or transdermal, with good results in the treatment of some diseases, including psoriasis.

In psoriasis treatment, Jain et al. used tacrolimus and curcumin loaded in a liposphere gel formulation and studied its effectiveness in psoriasis patients compared to a control formulation of both drugs in a solution [142]. Lipospheres of $47 \mathrm{~nm}$ were produced and incorporated to topical gel formulation. Furthermore, there was a study of distribution of the formulation, observing an improvement on the permeation in the different layers of the skin in mouse models. In addition, there was a study of the effectivity of the treatment compared to the use of the curcumin and tacrolimus solution, being observed as an enhanced performance and histopathological improvement with the lipospheres formulation. Moreover, there was a notable decrease in the levels of TNF- $\alpha$, IL-22, and IL-17 compared to actual treatment, suggesting that the use of lipospheres could be interesting in the development of new treatments for psoriasis.

\subsubsection{Ethosomes}

Ethosomes are vesicular carriers based on ethanol, phospholipids, and water for topical application. Their composition permits good skin penetration, due to their softness and flexibility, caused by the high ethanol concentration. The proposed mechanism for penetration enhancement by ethosomes is based on the dual effect of ethanol on both the lipid bilayers in the stratum corneum and in the vesicle: ethanol enables fluidization of the lipids in the ethosomal structure on one side, along with changes in the arrangement of the lipids in the skin barrier on the other side. This allows the soft vesicles to penetrate the altered structure of the stratum corneum and release the activity in the deeper layers of the skin [143].

In this area, Zhang et al. prepared ethosomes as a delivering system for psoralen, obtaining a particle size ranging from $56.71 \mathrm{~nm}$ to $159.07 \mathrm{~nm}$, showing the best entrapment efficiency ethosomes around $150 \mathrm{~nm}$ [144]. They studied the permeation of the drug compared to an ethanolic tincture of psoralen, observing a notable improvement (almost 7-times fold) in the deposition of the drug in rat skin. Conclusively, it was stated that the permeation and the penetration in the skin using ethosomes could decrease toxicity and increase the therapeutical effects in long-term therapy for skin disorders like psoriasis.

\subsubsection{Solid Lipid Nanoparticles}

Solid lipid nanoparticles (SLNs) are one of the newest lipid-based nanoparticles, formed by a blend of physiological lipid and surfactants [145]. These SLNs could be formed in different ways; the aquaphobic drug moiety would form them in a lipid medium or it could be dispersed to create a drug layer surrounding the lipid core [145]. Due to its composition, SLNs have many advantages, in comparison with other topical vehicles, such as controlled drug release, a decreasing of skin irritation, and protection for the active drugs. 
Moreover, their size permits an improvement in the permeation of the drug across the skin due to close contact between the nanocarrier and the stratum corneum [146,147]. Because of their characteristics, there is an increasing interest in their use for topical treatments in diseases like psoriasis [148].

In this context, Pradhan et al. determined the potential of SLNs for being used as a delivery system for a prolonged release of fluocinolone acetonide [149]. The nanoparticles were selected after an optimization process based on some indicators, such as size and drug loaded, which were determined by X-ray diffraction and a transmission electron microscope. The optimized formulation was achieved, with the formulation composition having $2 \%(w / v)$ lipid concentration, $1 \%(w / v)$ surfactant, and $0.06 \%(w / v)$ drug concentration. Particle size and entrapment efficiency of the optimized formulation were $107.4 \mathrm{~nm}$ $87 \%$, respectively, which represented a good agreement with the predicted values. There was a controlled prolonged release obeying Higuchi kinetics of drug release, whilst, in the suspension of the drug, there was a much quicker release, obeying zero order kinetics on skin models in vitro [121]. Furthermore, an increased concentration of fluocinolone acetonide on epidermis compared with the drug suspension was demonstrated. To sum up, it was demonstrated that the use of SNLs may be interesting in the development of new drug delivery systems to treat psoriasis.

\subsubsection{Nanostructured Lipid Carriers}

Nanostructured lipid carriers (NLCs) are an innovating nanocarrier produced from a blend of solid lipids with spatially incompatible liquid lipids [150,151]. NLCs have many advantages from other formulations, such as an increased drug loading, a controlled release of the drug, improved biocompatibility, enhanced bioavailability, and the possibility of being administrated by different routes, such as oral, pulmonary, intranasal, or topical. Demonstrated was a huge potential for NLCs as a drug delivery system in topical formulations, due to its enhancing penetration ability, which permits an increase of bioavailability.

Furthermore, there is an occlusion property of the NLCs, which make them unique, not allowing transepidermal water loss, increasing skin hydration by the formation of a monolayered lipid film over the surface of the skin [152]. These features have awakened some interest in the use of NCLs in new treatments for skin diseases like psoriasis.

Avasatthi et al. developed a nanostructure lipid carrier loaded with methotrexate, one of the most widely used drugs for psoriasis, in a nanogel formulation [153]. The optimized formula was obtained using Precirol ATO 5, resulting in methotrexate-NLC, with an average particle size of $278 \mathrm{~nm}$, a polydispersity index of 0.231 , and entrapment efficacy of $22.3 \%$. Effectiveness of this formulation was studied in vitro and in vivo, using the PASI score and an evaluation of histopathological characteristics. It was demonstrated that the use of the nanogel formulation had an increased effectiveness in the PASI score and had a prolonged life of circulation after $48 \mathrm{~h}$ of application. These results are relevant because they highlight the possibilities and potential of NLCs for new treatments for psoriasis.

\subsection{Microneedles}

Microneedle is a new drug delivery system, which consists of a base patch with perpendicular microneedles attached to bypass the stratum corneum. It is considered an intradermal drug delivery system, a new pharmaceutical form for psoriasis treatments. The patch has two parts; a base plate and the microneedles, which could be made of the same material or not. Microneedles must be strong and tough enough to perform their purpose with good mechanical resistance [154]. Moreover, the length of microneedles is between 25 to 2000 microns to assure their trespassing to the stratum corneum, but this is not long enough to activate the pain receptors in the skin, as shown below in Figure 4 .

Microneedles constitute an elegant solution to increase drugs bioavailability. The mechanism of this delivery system consists of an attachment of the microneedle patch on 
the skin, permitting a micro-sized channel through the skin layer. The main objective of the delivery system is helping to trespass the first barriers of the skin, allowing the delivered drug to deposit directly into the stratum corneum. This procedure improves the permeability capacity of the drug, enhancing bioavailability [155]. Due to the increasing interest in the use of microneedles, different types have been developed, with some differences in their mechanism and materials.

There are four general types of microneedles: solid microneedles, coated microneedles, dissolving microneedles, and hollow microneedles. The only type that has been studied for psoriasis is dissolving microneedles.

1)

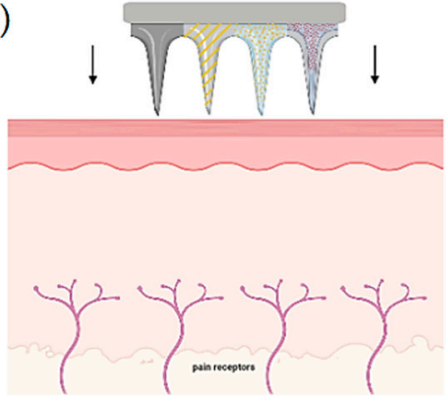

2)

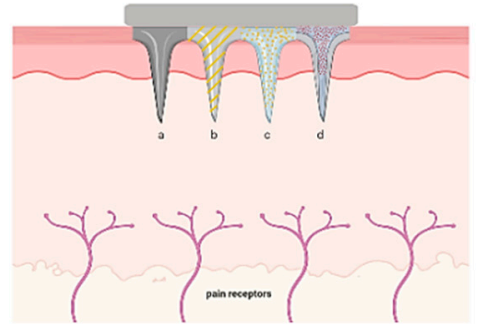

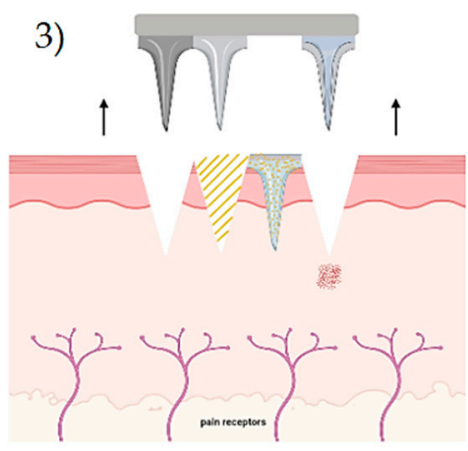

Figure 4. (1) Application of microneedles, (2) insertion, (3) extraction. Types of microneedles: (a) solid microneedles, (b) coated microneedles, (c) dissolving microneedles, and (d) hollow mi-croneedles.

Dissolving microneedles (DMNs) are produced with biodegradable materials, allowing them to dissolve themselves once they are in the skin [156]. The loaded drug in the needles is dissolved in the matrix of a polymer. The most important feature for the use of these microneedles is the material that the needles will be made of, which has to be strengthened enough to permit the perforation of the surficial layers of skin and show biodegradability without showing any toxicity. It must be considered that the material of the needles will be in the system of the patient. Therefore, microneedles have to be dissolved, circulate through the human body, and metabolized. One interesting feature of this type of microneedle is that drug release can be controlled by choosing the materials for the needles. Table 4 summarizes examples of biodegradable nanotechnology-based treatments for psoriasis. 
Table 4. Biodegradable nanotechnology-based treatments for psoriasis.

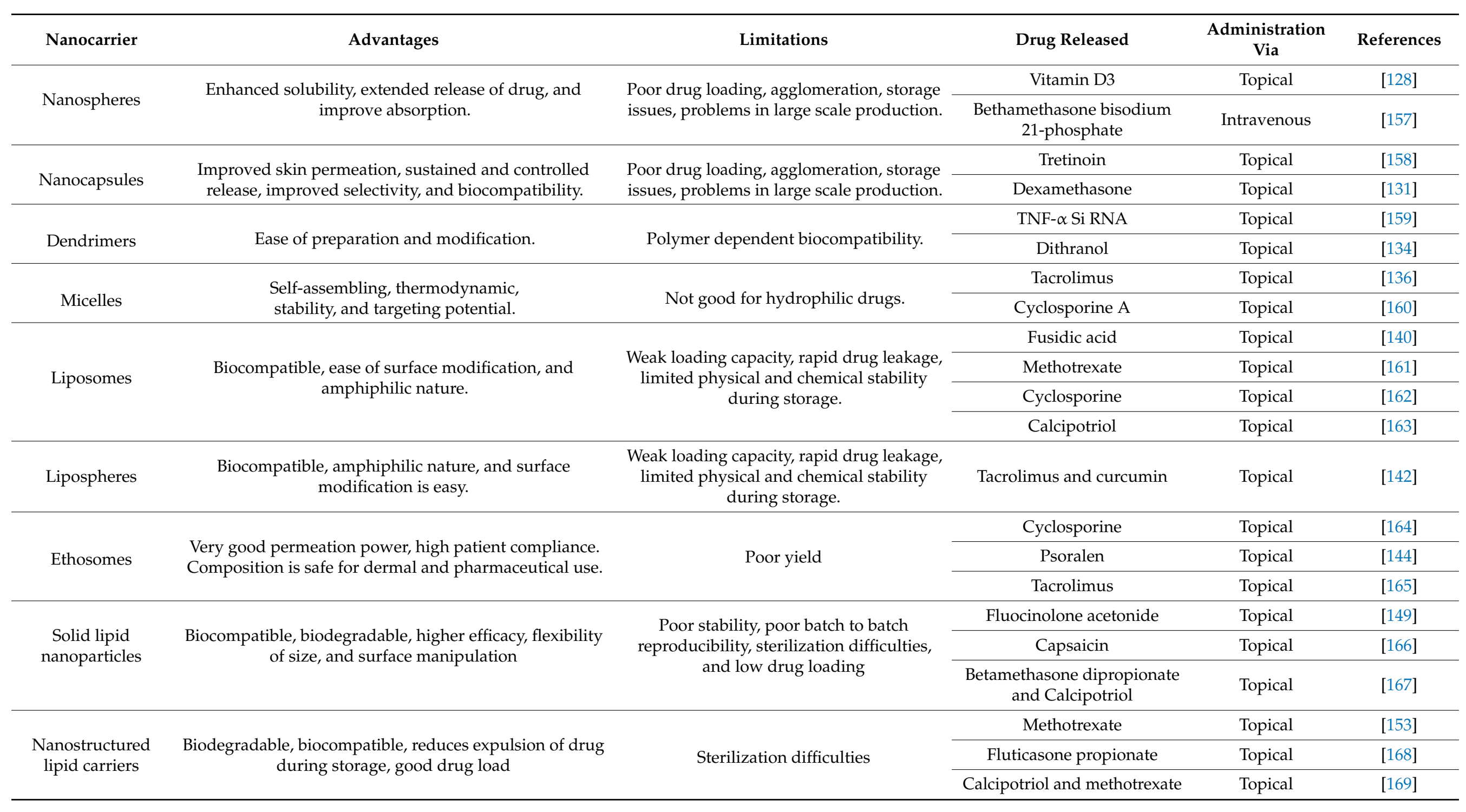


Tekko et al. studied the combination of nanotechnology and microneedles using nanocrystals loaded with methotrexate disodium [170]. Methodology, optimization, and characterization of the microneedle's patches with the nanocrystals were studied. The next step was studying their behavior in vitro, with interesting results on the release rates. Finally, an in vivo study was carried out with Sprague Dawley rats, comparing the use of microneedle patches with the usual administration route of methotrexate via oral administration. Their results suggest a successful insight into the use of microneedles in the delivery of methotrexate in rats, obtaining a sustained release of methotrexate during $72 \mathrm{~h}$ due to the drug retention capacity of the skin. Following these results, more studies are required to determine the efficacy of this new administration route in psoriatic models.

At present, there are still few studies that have used microneedles for drug delivery in psoriasis. Lee at el studied the safety and efficiency of using hyaluronic acid-dissolving microneedles with a cargo of methotrexate [171]. After studying the effects on 10 patients for 4 weeks, patient satisfaction was positive in general and there was a decrease in the PASI scores of their lesions. To sum up, an enhanced effectivity on the treatment was demonstrated, having a remarkable clinical effect on the study. However, more studies are necessary to confirm the data in this area, due to its small sample size and the lack of control groups.

\section{Conclusions}

Conventional drugs (i.e., commonly accepted as standard therapy or old class-level treatments), either administered by the oral or topical route, are still the backbone of the treatment of psoriasis. Nevertheless, we have witnesses emerging efforts towards the development of drugs and biosimilars with improved therapeutic outcomes, with less side effects and higher effectiveness. It is also true that new approaches, such as nanoparticles, have been proposed to promote new treatments. For this purpose, a wide range of nanoparticles is currently available, all of them with advantages and limitations. Nanoparticles based on a polymeric matrix, despite providing a controlled release of the loaded drug and improved permeation rates, may depict limited drug loading capacity and difficulties in scaling up the production lines. On the other hand, lipid-based nanoparticles may offer higher load capacity and encapsulation efficiency, in particular for poorly water-soluble drugs, and are biocompatible and may even act as absorption/penetration enhancers, given their lipid composition. Microneedles offer new solutions to the problems of conventional drugs, such as adverse-side effects, low bioavailability, or non-specificity in oral systemic treatments. Additionally, microneedles enhance permeation and increase specificity more than conventional topical treatments of different skin disorders. Despite the fact that only one type of microneedle has been applied in psoriasis treatment (dissolving microneedles), their results are really promising. These outcomes confirm that the use of this technology could be useful in the development of new drug formulations. To conclude, novel technologies, such as nanoparticles and microneedles and their combination, open a window to different perspectives to obtain innovative and effective treatments against psoriasis.

Author Contributions: R.G.P., A.C., A.O., M.E., J.P., and M.M. contributed to the conceptualization, methodology, validation, formal analysis, and investigation, and writing - original draft preparation. P.S., E.B.S., M.L.G., M.P., and E.S.-L. contributed to the supervision, writing-review and editing, project administration, resources, and funding acquisition. All authors have made a substantial contribution to the work. All authors have read and agreed to the published version of the manuscript.

Funding: This research was funded by the Portuguese Science and Technology Foundation (FCT/MCT) and European Funds (PRODER/COMPETE), under the project reference UIDB/04469/2020 (strategic fund), co-financed by FEDER, under the Partnership Agreement PT2020, granted to EBS.

Institutional Review Board Statement: Not applicable.

Informed Consent Statement: Not applicable.

Data Availability Statement: Not applicable. 
Conflicts of Interest: The authors declare no conflict of interest.

\section{References}

1. Samotij, D.; Nedoszytko, B.; Bartosińska, J.; Batycka-Baran, A.; Czajkowski, R.; Dobrucki, I.T.; Dobrucki, L.W.; GóreckaSokołowska, M.; Janaszak-Jasienicka, A.; Krasowska, D.; et al. Pathogenesis of psoriasis in the "omic" era. Part I. Epidemiology, clinical manifestation, immunological and neuroendocrine disturbances. Postepy Dermatol. Alergol. 2020, 37, 135-153. [CrossRef]

2. Rendon, A.; Schäkel, K. Psoriasis Pathogenesis and Treatment. Int. J. Mol. Sci. 2019, 20, 1475. [CrossRef] [PubMed]

3. Ortonne, J.; Chimenti, S.; Luger, T.; Puig, L.; Reid, F.; Trüeb, R.M. Scalp psoriasis: European consensus on grading and treatment algorithm. J. Eur. Acad. Dermatol. Venereol. JEADV 2009, 23, 1435-1444. [CrossRef] [PubMed]

4. Harden, J.L.; Krueger, J.G.; Bowcock, A.M. The immunogenetics of Psoriasis: A comprehensive review. J. Autoimmun. 2015, 64, 66-73. [CrossRef]

5. Howling, G.I.; Dettmar, P.W.; Goddard, P.A.; Hampson, F.C.; Dornish, M.; Wood, E.J. The effect of chitin and chitosan on the proliferation of human skin fibroblasts and keratinocytes in vitro. Biomaterials 2001, 22, 2959-2966. [CrossRef]

6. Morizane, S.; Gallo, R.L. Antimicrobial peptides in the pathogenesis of psoriasis. J. Dermatol. 2012, 39, 225-230. [CrossRef]

7. Morizane, S.; Yamasaki, K.; Mühleisen, B.; Kotol, P.F.; Murakami, M.; Aoyama, Y.; Iwatsuki, K.; Hata, T.; Gallo, R.L. Cathelicidin antimicrobial peptide LL-37 in psoriasis enables keratinocyte reactivity against TLR9 ligands. J. Investig. Dermatol. 2012, 132, 135-143. [CrossRef]

8. Liang, Y.; Sarkar, M.K.; Tsoi, L.C.; Gudjonsson, J.E. Psoriasis: A mixed autoimmune and autoinflammatory disease. Curr. Opin. Immunol. 2017, 49, 1-8. [CrossRef]

9. Girolomoni, G.; Strohal, R.; Puig, L.; Bachelez, H.; Barker, J.; Boehncke, W.H.; Prinz, J.C. The role of IL-23 and the IL-23/T(H) 17 immune axis in the pathogenesis and treatment of psoriasis. J. Eur. Acad. Dermatol. Venereol. JEADV 2017, 31, 1616-1626. [CrossRef]

10. Fotiadou, C.; Lazaridou, E.; Sotiriou, E.; Ioannides, D. Targeting IL-23 in psoriasis: Current perspectives. Psoriasis 2018, 8, 1-5. [CrossRef]

11. Mansouri, M.; Mansouri, P.; Raze, A.A.; Jadali, Z. The potential role of Th17 lymphocytes in patients with psoriasis. An. Bras. Dermatol. 2018, 93, 63-66. [CrossRef] [PubMed]

12. Ruan, Q.; Kameswaran, V.; Zhang, Y.; Zheng, S.; Sun, J.; Wang, J.; DeVirgiliis, J.; Liou, H.-C.; Beg, A.A.; Chen, Y.H. The Th17 immune response is controlled by the Rel-ROR $\gamma$-ROR $\gamma$ T transcriptional axis. J. Exp. Med. 2011, 208, 2321-2333. [CrossRef]

13. Zhang, Y.; Luo, X.-Y.; Wu, D.-H.; Xu, Y. ROR nuclear receptors: Structures, related diseases, and drug discovery. Acta Pharm. Sin 2015, 36, 71-87. [CrossRef] [PubMed]

14. Ecoeur, F.; Weiss, J.; Kaupmann, K.; Hintermann, S.; Orain, D.; Guntermann, C. Antagonizing Retinoic Acid-Related-Orphan Receptor Gamma Activity Blocks the T Helper 17/Interleukin-17 Pathway Leading to Attenuated Pro-inflammatory Human Keratinocyte and Skin Responses. Front. Immunol. 2019, 10. [CrossRef] [PubMed]

15. Cyr, P.; Bronner, S.M.; Crawford, J.J. Recent progress on nuclear receptor ROR $\gamma$ modulators. Bioorganic Med. Chem. Lett. 2016, 26, 4387-4393. [CrossRef]

16. Boutet, M.A.; Nerviani, A.; Gallo Afflitto, G.; Pitzalis, C. Role of the IL-23/IL-17 Axis in Psoriasis and Psoriatic Arthritis: The Clinical Importance of Its Divergence in Skin and Joints. Int. J. Mol. Sci. 2018, 19, 530. [CrossRef]

17. Hänsel, A.; Günther, C.; Ingwersen, J.; Starke, J.; Schmitz, M.; Bachmann, M.; Meurer, M.; Rieber, E.P.; Schäkel, K. Human slan (6-sulfo LacNAc) dendritic cells are inflammatory dermal dendritic cells in psoriasis and drive strong TH17/TH1 T-cell responses. J. Allergy Clin. Immunol. 2011, 127, 787-794.e9. [CrossRef]

18. Diluvio, L.; Vollmer, S.; Besgen, P.; Ellwart, J.W.; Chimenti, S.; Prinz, J.C. Identical TCR beta-chain rearrangements in streptococcal angina and skin lesions of patients with psoriasis vulgaris. J. Immunol. 2006, 176, 7104-7111. [CrossRef]

19. Georgescu, S.R.; Tampa, M.; Caruntu, C.; Sarbu, M.I.; Mitran, C.I.; Mitran, M.I.; Matei, C.; Constantin, C.; Neagu, M. Advances in Understanding the Immunological Pathways in Psoriasis. Int. J. Mol. Sci. 2019, 20, 739. [CrossRef]

20. Matsuzaki, G.; Umemura, M. Interleukin-17 family cytokines in protective immunity against infections: Role of hematopoietic cell-derived and non-hematopoietic cell-derived interleukin-17s. Microbiol. Immunol. 2018, 62, 1-13. [CrossRef]

21. Gaffen, S.L. Structure and signalling in the IL-17 receptor family. Nat. Rev. Immunol. 2009, 9, 556-567. [CrossRef]

22. Lee, J.S.; Tato, C.M.; Joyce-Shaikh, B.; Gulen, M.F.; Cayatte, C.; Chen, Y.; Blumenschein, W.M.; Judo, M.; Ayanoglu, G.; McClanahan, T.K.; et al. Interleukin-23-Independent IL-17 Production Regulates Intestinal Epithelial Permeability. Immunity 2015, 43, 727-738. [CrossRef]

23. Schmitt, J.; Rosumeck, S.; Thomaschewski, G.; Sporbeck, B.; Haufe, E.; Nast, A. Efficacy and safety of systemic treatments for moderate-to-severe psoriasis: Meta-analysis of randomized controlled trials. Br. J. Dermatol. 2014, 170, 274-303. [CrossRef]

24. Leonardi, C.L.; Romiti, R.; Tebbey, P.W. Ten years on: The impact of biologics on the practice of dermatology. Dermatol. Clin. 2015, 33, 111-125. [CrossRef] [PubMed]

25. Robinson, A.; Van Voorhees, A.S.; Hsu, S.; Korman, N.J.; Lebwohl, M.G.; Bebo, B.F., Jr.; Kalb, R.E. Treatment of pustular psoriasis: From the Medical Board of the National Psoriasis Foundation. J. Am. Acad. Dermatol. 2012, 67, 279-288. [CrossRef]

26. Johnston, A.; Xing, X.; Wolterink, L.; Barnes, D.H.; Yin, Z.; Reingold, L.; Kahlenberg, J.M.; Harms, P.W.; Gudjonsson, J.E. IL-1 and IL-36 are dominant cytokines in generalized pustular psoriasis. J. Allergy Clin. Immunol. 2017, 140, 109-120. [CrossRef] 
27. Onoufriadis, A.; Simpson, M.A.; Pink, A.E.; Di Meglio, P.; Smith, C.H.; Pullabhatla, V.; Knight, J.; Spain, S.L.; Nestle, F.O.; Burden, A.D.; et al. Mutations in IL36RN/IL1F5 are associated with the severe episodic inflammatory skin disease known as generalized pustular psoriasis. Am. J. Hum. Genet. 2011, 89, 432-437. [CrossRef] [PubMed]

28. Marrakchi, S.; Guigue, P.; Renshaw, B.R.; Puel, A.; Pei, X.Y.; Fraitag, S.; Zribi, J.; Bal, E.; Cluzeau, C.; Chrabieh, M.; et al. Interleukin-36-receptor antagonist deficiency and generalized pustular psoriasis. N. Engl. J. Med. 2011, 365, 620-628. [CrossRef] [PubMed]

29. Navarini, A.A.; Burden, A.D.; Capon, F.; Mrowietz, U.; Puig, L.; Köks, S.; Kingo, K.; Smith, C.; Barker, J.N. European consensus statement on phenotypes of pustular psoriasis. J. Eur. Acad. Dermatol. Venereol. JEADV 2017, 31, 1792-1799. [CrossRef]

30. Ko, H.C.; Jwa, S.W.; Song, M.; Kim, M.B.; Kwon, K.S. Clinical course of guttate psoriasis: Long-term follow-up study. J. Dermatol. 2010, 37, 894-899. [CrossRef] [PubMed]

31. Leung, D.Y.; Travers, J.B.; Giorno, R.; Norris, D.A.; Skinner, R.; Aelion, J.; Kazemi, L.V.; Kim, M.H.; Trumble, A.E.; Kotb, M.; et al. Evidence for a streptococcal superantigen-driven process in acute guttate psoriasis. J. Clin. Investig. 1995, 96, 2106-2112. [CrossRef] [PubMed]

32. Johnston, A.; Gudjonsson, J.E.; Sigmundsdottir, H.; Love, T.J.; Valdimarsson, H. Peripheral blood T cell responses to keratin peptides that share sequences with streptococcal M proteins are largely restricted to skin-homing CD8(+) T cells. Clin. Exp. Immunol. 2004, 138, 83-93. [CrossRef] [PubMed]

33. Micali, G.; Verzì, A.E.; Giuffrida, G.; Panebianco, E.; Musumeci, M.L.; Lacarrubba, F. Inverse Psoriasis: From Diagnosis to Current Treatment Options. Clin. Cosmet. Investig. Dermatol. 2019, 12, 953-959. [CrossRef] [PubMed]

34. Syed, Z.U.; Khachemoune, A. Inverse psoriasis: Case presentation and review. Am. J. Clin. Dermatol. 2011, 12, 143-146. [CrossRef]

35. Mrowietz, U.; Kragballe, K.; Reich, K.; Spuls, P.; Griffiths, C.E.; Nast, A.; Franke, J.; Antoniou, C.; Arenberger, P.; Balieva, F.; et al. Definition of treatment goals for moderate to severe psoriasis: A European consensus. Arch. Dermatol. Res. 2011, 303, 1-10. [CrossRef] [PubMed]

36. Torsekar, R.; Gautam, M.M. Topical Therapies in Psoriasis. Indian Dermatol. Online J. 2017, 8, 235-245. [CrossRef]

37. Stein Gold, L.F. Topical Therapies for Psoriasis: Improving Management Strategies and Patient Adherence. Semin. Cutan. Med. Surg. 2016, 35, S36-S44. [CrossRef]

38. Kim, W.B.; Jerome, D.; Yeung, J. Diagnosis and management of psoriasis. Can. Fam. Physician 2017, 63, 278-285.

39. Psomadakis, C.E.; Han, G. New and Emerging Topical Therapies for Psoriasis and Atopic Dermatitis. J. Clin. Aesthetic Dermatol. 2019, 12, 28-34.

40. Armstrong, A.W.; Read, C. Pathophysiology, Clinical Presentation, and Treatment of Psoriasis: A Review. JAMA 2020, 323, 1945-1960. [CrossRef]

41. Piotrowska, A.; Wierzbicka, J.; Żmijewski, M.A. Vitamin D in the skin physiology and pathology. Acta Biochim. Pol. 2016, 63, 17-29. [CrossRef]

42. Wadhwa, B.; Relhan, V.; Goel, K.; Kochhar, A.M.; Garg, V.K. Vitamin D and skin diseases: A review. Indian J. Dermatol. Venereol. Leprol. 2015, 81, 344-355. [CrossRef]

43. Barrea, L.; Savanelli, M.C.; Di Somma, C.; Napolitano, M.; Megna, M.; Colao, A.; Savastano, S. Vitamin D and its role in psoriasis: An overview of the dermatologist and nutritionist. Rev. Endocr. Metab. Disord. 2017, 18, 195-205. [CrossRef] [PubMed]

44. Mattozzi, C.; Paolino, G.; Richetta, A.G.; Calvieri, S. Psoriasis, vitamin D and the importance of the cutaneous barrier's integrity: An update. J. Dermatol. 2016, 43, 507-514. [CrossRef]

45. Filoni, A.; Vestita, M.; Congedo, M.; Giudice, G.; Tafuri, S.; Bonamonte, D. Association between psoriasis and vitamin D: Duration of disease correlates with decreased vitamin D serum levels: An observational case-control study. Medicine 2018, 97 , e11185. [CrossRef] [PubMed]

46. Lee, Y.H.; Song, G.G. Association between circulating 25-hydroxyvitamin D levels and psoriasis, and correlation with disease severity: A meta-analysis. Clin. Exp. Dermatol. 2018, 43, 529-535. [CrossRef] [PubMed]

47. Giustina, A.; Bouillon, R.; Binkley, N.; Sempos, C.; Adler, R.A.; Bollerslev, J.; Dawson-Hughes, B.; Ebeling, P.R.; Feldman, D.; Heijboer, A.; et al. Controversies in Vitamin D: A Statement from the Third International Conference. JBMR Plus 2020, 4 , e10417. [CrossRef] [PubMed]

48. Hambly, R.; Kirby, B. The relevance of serum vitamin D in psoriasis: A review. Arch. Dermatol. Res. 2017, 309, 499-517. [CrossRef]

49. Umar, M.; Sastry, K.S.; Al Ali, F.; Al-Khulaifi, M.; Wang, E.; Chouchane, A.I. Vitamin D and the Pathophysiology of Inflammatory Skin Diseases. Ski. Pharmacol. Physiol. 2018, 31, 74-86. [CrossRef]

50. Jones, G. The discovery and synthesis of the nutritional factor vitamin D. Int. J. Paleopathol. 2018, 23, 96-99. [CrossRef] [PubMed]

51. Jarrett, P.; Scragg, R. A short history of phototherapy, vitamin D and skin disease. Photochem. Photobiol. Sci. Off. J. Eur. Photochem. Assoc. Eur. Soc. Photobiol. 2017, 16, 283-290. [CrossRef]

52. Juzeniene, A.; Grigalavicius, M.; Juraleviciute, M.; Grant, W.B. Phototherapy and vitamin D. Clin. Dermatol. 2016, 34, 548-555. [CrossRef]

53. Lee, Y.H. Vitamin D receptor ApaI, TaqI, BsmI, and FokI polymorphisms and psoriasis susceptibility: An updated meta-analysis. Clin. Exp. Dermatol. 2019, 44, 498-505. [CrossRef]

54. Liu, J.; Wang, W.; Liu, K.; Wan, D.; Wu, Z.; Cao, Z.; Luo, Y.; Xiao, C.; Yin, M. Vitamin D receptor gene polymorphisms are associated with psoriasis susceptibility and the clinical response to calcipotriol in psoriatic patients. Exp. Dermatol. 2020, 29, 1186-1190. [CrossRef] 
55. Slominski, A.T.; Kim, T.K.; Li, W.; Yi, A.K.; Postlethwaite, A.; Tuckey, R.C. The role of CYP11A1 in the production of vitamin D metabolites and their role in the regulation of epidermal functions. J. Steroid Biochem. Mol. Biol. 2014, 144 Pt A, 28-39. [CrossRef]

56. Lang, P.O.; Aspinall, R. Vitamin D Status and the Host Resistance to Infections: What It Is Currently (Not) Understood. Clin. Ther. 2017, 39, 930-945. [CrossRef] [PubMed]

57. Jenkinson, C. The vitamin D metabolome: An update on analysis and function. Cell Biochem. Funct. 2019, 37, 408-423. [CrossRef] [PubMed]

58. Tuckey, R.C.; Li, W.; Shehabi, H.Z.; Janjetovic, Z.; Nguyen, M.N.; Kim, T.K.; Chen, J.; Howell, D.E.; Benson, H.A.; Sweatman, T.; et al. Production of 22-hydroxy metabolites of vitamin d3 by cytochrome p450scc (CYP11A1) and analysis of their biological activities on skin cells. Drug Metab. Dispos. Biol. Fate Chem. 2011, 39, 1577-1588. [CrossRef] [PubMed]

59. Wierzbicka, J.; Piotrowska, A.; Żmijewski, M.A. The renaissance of vitamin D. Acta Biochim. Pol. 2014, 61, 679-686. [CrossRef]

60. Gao, C.; Liao, M.Z.; Han, L.W.; Thummel, K.E.; Mao, Q. Hepatic Transport of 25-Hydroxyvitamin D(3) Conjugates: A Mechanism of 25-Hydroxyvitamin D(3) Delivery to the Intestinal Tract. Drug Metab. Dispos. Biol. Fate Chem. 2018, 46, 581-591. [CrossRef] [PubMed]

61. Farahnik, B.; Patel, V.; Beroukhim, K.; Zhu, T.H.; Abrouk, M.; Nakamura, M.; Singh, R.; Lee, K.; Bhutani, T.; Koo, J. Combining biologic and phototherapy treatments for psoriasis: Safety, efficacy, and patient acceptability. Psoriasis 2016, 6, 105-111. [CrossRef]

62. Young, M.; Aldredge, L.; Parker, P. Psoriasis for the primary care practitioner. J. Am. Assoc. Nurse Pract. 2017, 29, 157-178. [CrossRef]

63. Perrone, V.; Sangiorgi, D.; Buda, S.; Degli Esposti, L. Topical medication utilization and health resources consumption in adult patients affected by psoriasis: Findings from the analysis of administrative databases of local health units. ClinicoEconomics Outcomes Res. 2017, 9, 181-188. [CrossRef]

64. Pathak, S.N.; Scott, P.; West, C.E.; Feldman, S.R. Self-management in patients with psoriasis. Psoriasis Targets Ther. 2014, 4, 19-26.

65. Dattola, A.; Silvestri, M.; Bennardo, L.; Passante, M.; Rizzuto, F.; Dastoli, S.; Patruno, C.; Bianchi, L.; Nisticò, S.P. A novel vehicle for the treatment of psoriasis. Dermatol. Ther. 2020, 33, e13185. [CrossRef]

66. Pinzon, M.I.; Garcia, O.R.; Villa, C.C. The influence of Aloe vera gel incorporation on the physicochemical and mechanical properties of banana starch-chitosan edible films. J. Sci. Food Agric. 2018, 98, 4042-4049. [CrossRef]

67. Fluhr, J.W.; Cavallotti, C.; Berardesca, E. Emollients, moisturizers, and keratolytic agents in psoriasis. Clin. Dermatol. 2008, 26, 380-386. [CrossRef]

68. Nola, I.; Kostović, K.; Kotrulja, L.; Lugović, L. The use of emollients as sophisticated therapy in dermatology. Acta Dermatovenerol. Croat. Adc 2003, 11, 80-87. [PubMed]

69. Arbiser, J.L.; Govindarajan, B.; Battle, T.E.; Lynch, R.; Frank, D.A.; Ushio-Fukai, M.; Perry, B.N.; Stern, D.F.; Bowden, G.T.; Liu, A.; et al. Carbazole is a naturally occurring inhibitor of angiogenesis and inflammation isolated from antipsoriatic coal tar. J. Investig. Dermatol. 2006, 126, 1396-1402. [CrossRef]

70. Lebwohl, M. The role of salicylic acid in the treatment of psoriasis. Int. J. Dermatol. 1999, 38, 16-24. [CrossRef] [PubMed]

71. Wang, C.; Lin, A. Efficacy of topical calcineurin inhibitors in psoriasis. J. Cutan. Med. Surg. 2014, 18, 8-14. [CrossRef]

72. Duvic, M.; Asano, A.T.; Hager, C.; Mays, S. The pathogenesis of psoriasis and the mechanism of action of tazarotene. J. Am. Acad. Dermatol. 1998, 39, S129-S133. [CrossRef]

73. Weinstein, G.D.; Koo, J.Y.; Krueger, G.G.; Lebwohl, M.G.; Lowe, N.J.; Menter, M.A.; Lew-Kaya, D.A.; Sefton, J.; Gibson, J.R.; Walker, P.S. Tazarotene cream in the treatment of psoriasis: Two multicenter, double-blind, randomized, vehicle-controlled studies of the safety and efficacy of tazarotene creams $0.05 \%$ and $0.1 \%$ applied once daily for 12 weeks. J. Am. Acad. Dermatol. 2003, 48 , 760-767. [CrossRef]

74. McGill, A.; Frank, A.; Emmett, N.; Turnbull, D.M.; Birch-Machin, M.A.; Reynolds, N.J. The anti-psoriatic drug anthralin accumulates in keratinocyte mitochondria, dissipates mitochondrial membrane potential, and induces apoptosis through a pathway dependent on respiratory competent mitochondria. Faseb J. Off. Publ. Fed. Am. Soc. Exp. Biol. 2005, 19, 1012-1014. [CrossRef]

75. Hengge, U.R.; Ruzicka, T.; Schwartz, R.A.; Cork, M.J. Adverse effects of topical glucocorticosteroids. J. Am. Acad. Dermatol. 2006, 54, 1-15. [CrossRef]

76. Van De Kerkhof, P.C.M.; Berth-Jones, J.; Griffiths, C.E.M.; Harrison, P.V.; Hönigsmann, H.; Marks, R.; Roelandts, R.; Schöpf, E.; Trompke, C. Long-term efficacy and safety of tacalcitol ointment in patients with chronic plaque psoriasis. Br. J. Dermatol. 2002, 146, 414-422. [CrossRef] [PubMed]

77. Lee, C.S.; Li, K. A review of acitretin for the treatment of psoriasis. Expert Opin. Drug Saf. 2009, 8, 769-779. [CrossRef]

78. Smith, D. Fumaric acid esters for psoriasis: A systematic review. Ir. J. Med. Sci. 2017, 186, 161-177. [CrossRef] [PubMed]

79. Dogra, S.; Mahajan, R.; Narang, T.; Handa, S.; Dogra, S.; Mahajan, R.; Narang, T.; Handa, S. Systemic cyclosporine treatment in severe childhood psoriasis: A retrospective chart review Systemic cyclosporine treatment in severe childhood psoriasis: A retrospective chart review. J. Dermatolog. Treat. 2017, 6634. [CrossRef]

80. Greb, J.E.; Goldminz, A.M.; Gottlieb, A.B. Insights on methotrexate in psoriatic disease. Clin. Immunol. 2016, 172, 61-64. [CrossRef]

81. Keating, G.M. Apremilast: A Review in Psoriasis and Psoriatic Arthritis. Drugs 2017, 77, 459-472. [CrossRef] [PubMed]

82. Azevedo, A.; Torres, T. Tofacitinib: A New Oral Therapy for Psoriasis. Clin. Drug Investig. 2018, 38, 101-112. [CrossRef] [PubMed]

83. Dapavo, P. Vujic.I.; Fierro, M.T.; Quaglino, P.; Samlorenzo, M. The infliximab biosimilar in the treatment of moderate to severe plaque psoriasis. Pract. Nurs. 2008, 19, 560-565. [CrossRef] 
84. Leonardi, C.L.; Powers, J.L.; Matheson, R.T.; Goffe, B.S.; Zitnik, R.; Wang, A.; Gottlieb, A.B. Etanercept as Monotherapy in Patients with Psoriasis. N. Engl. J. Med. 2003, 349, 2014-2022. [CrossRef]

85. Berends, M.A.M.; Driessen, R.J.B.; Langewouters, A.M.G.; Boezeman, J.B.; Van De Kerkhof, P.C.M.; De Jong, E.M.G.J. Etanercept and efalizumab treatment for high-need psoriasis. Effects and side effects in a prospective cohort study in outpatient clinical practice. J. Dermatolog. Treat. 2007, 18, 76-83. [CrossRef]

86. Alwawi, E.A.; Mehlis, S.L.; Gordon, K.B. Treating psoriasis with adalimumab. Ther. Clin. Risk Manag. 2008, 4, 345-351. [CrossRef] [PubMed]

87. Chimenti, M.S.; Saraceno, R.; Chiricozzi, A.; Giunta, A.; Chimenti, S.; Perricone, R. Profile of certolizumab and its potential in the treatment of psoriatic arthritis. Open Access Rheumatol. Res. Rev. 2013, 6, 7-13. [CrossRef]

88. Fleischmann, R.; Vencovsky, J.; Van Vollenhoven, R.F.; Borenstein, D.; Box, J.; Coteur, G.; Goel, N.; Brezinschek, H.P.; Innes, A.; Strand, V. Efficacy and safety of certolizumab pegol monotherapy every 4 weeks in patients with rheumatoid arthritis failing previous disease-modifying antirheumatic therapy: The FAST4WARD study. Ann. Rheum. Dis. 2009, 68, 805-811. [CrossRef]

89. Leonardi, C.L.; Kimball, A.B.; Papp, K.A. Efficacy and safety of ustekinumab, a human interleukin-12/23 monoclonal antibody, in patients with psoriasis: 76-Week results from a randomised, double-blind, placebo-controlled trial (PHOENIX 1). Lancet 2008, 24, 34. [CrossRef]

90. Langley, R.G.; Elewski, B.E.; Lebwohl, M.; Reich, K.; Griffiths, C.E.M.; Papp, K.; Puig, L.; Nakagawa, H.; Spelman, L.; Sigurgeirsson, B.; et al. Secukinumab in plaque psoriasis-Results of two phase 3 trials. N. Engl. J. Med. 2014, 371, 326-338. [CrossRef]

91. Glatt, S.; Helmer, E.; Haier, B.; Strimenopoulou, F.; Price, G.; Vajjah, P.; Harari, O.A.; Lambert, J.; Shaw, S. First-in-human randomized study of bimekizumab, a humanized monoclonal antibody and selective dual inhibitor of IL-17A and IL-17F, in mild psoriasis. Br. J. Clin. Pharmacol. 2017, 83, 991-1001. [CrossRef]

92. Reich, K. Anti-interleukin-17 monoclonal antibody ixekizumab in psoriasis. N. Engl. J. Med. 2012, 367, 274-275. [CrossRef] [PubMed]

93. Gordon, K.B.; Blauvelt, A.; Papp, K.A.; Langley, R.G.; Luger, T.; Ohtsuki, M.; Reich, K.; Amato, D.; Ball, S.G.; Braun, D.K.; et al. Phase 3 trials of ixekizumab in moderate-to-severe plaque psoriasis. N. Engl. J. Med. 2016, 375, 345-356. [CrossRef]

94. Krueger, J.G.; Kricorian, G.; Aras, G.; Ph, D.; Li, J.; Russell, C.B.; Thompson, E.H.Z.; Baumgartner, S. Brodalumab, an AntiInterleukin-17-Receptor Antibody for Psoriasis. N. Engl. J. Med. 2012, 366, 1181-1189.

95. Papp, K.; Thaçi, D.; Reich, K.; Riedl, E.; Langley, R.G.; Krueger, J.G.; Gottlieb, A.B.; Nakagawa, H.; Bowman, E.P.; Mehta, A.; et al. Tildrakizumab (MK-3222), an anti-interleukin-23p19 monoclonal antibody, improves psoriasis in a phase IIb randomized placebo-controlled trial. Br. J. Dermatol. 2015, 173, 930-939. [CrossRef]

96. Nakamura, M.; Lee, K.; Jeon, C.; Sekhon, S.; Afifi, L.; Yan, D.; Lee, K.; Bhutani, T. Guselkumab for the Treatment of Psoriasis: A Review of Phase III Trials. Dermatol. Ther. 2017, 7, 281-292. [CrossRef]

97. Sofen, H.; Smith, S.; Matheson, R.T.; Leonardi, C.L.; Calderon, C.; Brodmerkel, C.; Li, K.; Campbell, K.; Marciniak, S.J.; Wasfi, Y.; et al. Guselkumab (an IL-23-specific mAb) demonstrates clinical and molecular response in patients with moderate-to-severe psoriasis. J. Allergy Clin. Immunol. 2014, 133, 1032-1040. [CrossRef]

98. Gordon, K.B.; Strober, B.; Lebwohl, M.; Augustin, M.; Blauvelt, A.; Poulin, Y.; Papp, K.A.; Sofen, H.; Puig, L.; Foley, P.; et al. Efficacy and safety of risankizumab in moderate-to-severe plaque psoriasis (UltIMMa-1 and UltIMMa-2): Results from two double-blind, randomised, placebo-controlled and ustekinumab-controlled phase 3 trials. Lancet 2018, 392, 650-661. [CrossRef]

99. Reich, K.; Rich, P.; Maari, C.; Bissonnette, R.; Leonardi, C.; Menter, A.; Igarashi, A.; Klekotka, P.; Patel, D.; Li, J.; et al. Efficacy and safety of mirikizumab (LY3074828) in the treatment of moderate-to-severe plaque psoriasis: Results from a randomized phase II study. Br. J. Dermatol. 2019, 181, 88-95. [CrossRef] [PubMed]

100. Iannone, L.F.; Bennardo, L.; Palleria, C.; Roberti, R.; De Sarro, C.; Naturale, M.D.; Dastoli, S.; Donato, L.; Manti, A.; Valenti, G.; et al. Safety profile of biologic drugs for psoriasis in clinical practice: An Italian prospective pharmacovigilance study. PLoS ONE 2020, 15, e0241575. [CrossRef] [PubMed]

101. Boston Pharmaceuticals. Study to Evaluate the Safety, Tolerability, and Pharmacokinetics of Single and Repeat Topical Administration of BOS-475 in Healthy Subjects and Patients with Psoriasis; U.S. Food and Drug Administration: Silver Spring, MD, USA, 2020.

102. AbbVie. A Study to Evaluate the Pharmacokinetics, Safety and Tolerability of ABBV-157 in Healthy Volunteers and in Participants with Chronic Plaque Psoriasis; U.S. Food and Drug Administration: Silver Spring, MD, USA, 2019.

103. Celgene. A Safety Study of CC-92252 in Healthy Adult Subjects and Adult Subjects with Psoriasis; U.S. Food and Drug Administration: Silver Spring, MD, USA, 2018.

104. Evelo Biosciences, I. A Study of EDP1066 in Healthy Participants and Participants with Mild to Moderate Psoriasis and Atopic Dermatitis; U.S. Food and Drug Administration: Silver Spring, MD, USA, 2018.

105. Evelo Biosciences, I. A Study of EDP1815 in Healthy Participants and Participants with Mild to Moderate Psoriasis and Atopic Dermatitis; U.S. Food and Drug Administration: Silver Spring, MD, USA, 2018.

106. Affibody. A Study to Evaluate ABY-035 in Subjects with Moderate-to-severe Plaque Psoriasis (AFFIRM-35); U.S. Food and Drug Administration: Silver Spring, MD, USA, 2018.

107. Arcutis Biotherapeutics, I. Safety, Pharmacokinetics and Efficacy of ARQ-151 Cream in Adults with Mild to Moderate Chronic Plaque Psoriasis; U.S. Food and Drug Administration: Silver Spring, MD, USA, 2018.

108. Boehringer, I. A Study to Test. How Well Patients with Plaque Psoriasis Tolerate BI 730357 over a Longer Period and How Effective It Is; U.S. Food and Drug Administration: Silver Spring, MD, USA, 2019. 
109. Santalis Pharmaceuticals Inc. A Trial of a Botanical Drug (EISO) for Treatment of Mild-to-Moderate Plaque Psoriasis; U.S. Food and Drug Administration: Silver Spring, MD, USA, 2019.

110. Akros Pharma Inc. Study to Evaluate the Efficacy and Safety of JTE-451 in Subjects with Moderate to Severe Plaque Psoriasis (IMPACT-PS); U.S. Food and Drug Administration: Silver Spring, MD, USA, 2019.

111. Bond Avillion 2 Development LP. A Phase $2 b$ Study of the Efficacy, Safety, and Tolerability of M1095 in Subjects with Moderate to Severe Psoriasis; U.S. Food and Drug Administration: Silver Spring, MD, USA, 2017.

112. Pfizer. Dose Ranging Study to Assess. Efficacy, Safety and Tolerability of PF-06700841 Topical Cream in Psoriasis; U.S. Food and Drug Administration: Silver Spring, MD, USA, 2019.

113. Pfizer. A Study to Evaluate Safety and Efficacy of PF-06826647 for Moderate to Severe Plaque Psoriasis; U.S. Food and Drug Administration: Silver Spring, MD, USA, 2019.

114. Jiangsu Hengrui Medicine Company Ltd. A Clinical Study of SHR-1314 Injection in the Treatment of Moderate to Severe Plaque Psoriasis in Adults; U.S. Food and Drug Administration: Silver Spring, MD, USA, 2019.

115. Bristol-Myers Squibb. An. Investigational Study to Evaluate Experimental Medication BMS-986165 Compared to Placebo and a Currently Available Treatment in Participants with Moderate-to-Severe Plaque Psoriasis (POETYK-PSO-2); U.S. Food and Drug Administration: Silver Spring, MD, USA, 2018.

116. Biocad. Clinical Study of Efficacy and Safety of BCD-085 (Monoclonal Anti-IL-17 Antibody) in Psoriatic Arthritis (PATERA); U.S. Food and Drug Administration: Silver Spring, MD, USA, 2018.

117. Boehringer, I. The VOLTAIRE-X Trial Looks at the Effect of Switching Between Humira ${ }^{\circledR}$ and BI 695501 in Patients with Plaque Psoriasis; U.S. Food and Drug Administration: Silver Spring, MD, USA, 2017.

118. Can-Fite BioPharma Ltd. CF101 Therapy in Patients with Moderate-to-Severe Plaque Psoriasis; U.S. Food and Drug Administration: Silver Spring, MD, USA, 2017.

119. Coherus Biosciences, Inc. Comparison of CHS-1420 Versus Humira in Subjects with Chronic Plaque Psoriasis (PsOsim); U.S. Food and Drug Administration: Silver Spring, MD, USA, 2019.

120. Gilead Sciences. Study to Evaluate the Efficacy and Safety of Filgotinib in Participants with Active Psoriatic Arthritis Who Are Naive to Biologic DMARD Therapy (PENGUIN 1); U.S. Food and Drug Administration: Silver Spring, MD, USA, 2019.

121. Pradhan, M.; Alexander, A.; Singh, M.R.; Singh, D.; Saraf, S.; Saraf, S.; Ajazuddin. Understanding the prospective of nanoformulations towards the treatment of psoriasis. Biomed. Pharmacother. 2018, 107, 447-463. [CrossRef]

122. Menlo Therapeutics Inc. Study of the Long Term Safety of Serlopitant for the Treatment of Pruritus (Itch); U.S. Food and Drug Administration: Silver Spring, MD, USA, 2018.

123. Dermavant Sciences GmbH. Long Term Extension Study of Tapinarof for Plaque Psoriasis in Adults; U.S. Food and Drug Administration: Silver Spring, MD, USA, 2019.

124. Sun Pharma Global Fze. A Study to Evaluate the Efficacy and Safety/Tolerability of Subcutaneous Tildrakizumab (SCH 900222/MK-3222) in Participants with Moderate-to-Severe Chronic Plaque Psoriasis Followed by a Long-term Extension Study (MK-3222-011) (reSURFACE 2); U.S. Food and Drug Administration: Silver Spring, MD, USA, 2018.

125. AbbVie. A Study Comparing Upadacitinib (ABT-494) to Placebo in Participants with Active Psoriatic Arthritis Who Have a History of Inadequate Response to at Least One Biologic Disease Modifying Anti-Rheumatic Drug (SELECT_PsA 2); U.S. Food and Drug Administration: Silver Spring, MD, USA, 2017.

126. Lombardo, D.; Kiselev, M.A.; Caccamo, M.T. Smart Nanoparticles for Drug Delivery Application: Development of Versatile Nanocarrier Platforms in Biotechnology and Nanomedicine. J. Nanomater. 2019, 2019, 3702518. [CrossRef]

127. Batheja, P.; Sheihet, L.; Kohn, J.; Singer, A.J.; Michniak-Kohn, B. Topical drug delivery by a polymeric nanosphere gel: Formulation optimization and in vitro and in vivo skin distribution studies. J. Control. Release 2011, 149, 159-167. [CrossRef]

128. Diering. Polymeric Nanospheres for Topical Delivery of Vitamin D3. Physiol. Behav. 2018, 176, 139-148. [CrossRef]

129. Mora-Huertas, C.E.; Fessi, H.; Elaissari, A. Polymer-based nanocapsules for drug delivery. Int. J. Pharm. 2010, $385,113-142$. [CrossRef]

130. Barbosa, T.C.; Nascimento, L.E.D.; Bani, C.; Almeida, T.; Nery, M.; Santos, R.S.; Menezes, L.R.O.; Zielinska, A.; Fernandes, A.R.; Cardoso, J.C.; et al. Development, Cytotoxicity and Eye Irritation Profile of a New Sunscreen Formulation Based on Benzophenone-3-poly(epsilon-caprolactone) Nanocapsules. Toxics 2019, 7, 51. [CrossRef]

131. Marchiori, M.L.; Lubini, G.; Dalla Nora, G.; Friedrich, R.B.; Fontana, M.C.; Ourique, A.F.; Bastos, M.O.; Rigo, L.A.; Silva, C.B.; Tedesco, S.B.; et al. Hydrogel containing dexamethasone-loaded nanocapsules for cutaneous administration: Preparation, characterization, and in vitro drug release study. Drug Dev. Ind. Pharm. 2010, 36, 962-971. [CrossRef] [PubMed]

132. Mignani, S.; El Kazzouli, S.; Bousmina, M.; Majoral, J.P. Expand classical drug administration ways by emerging routes using dendrimer drug delivery systems: A concise overview. Adv. Drug Deliv. Rev. 2013, 65, 1316-1330. [CrossRef] [PubMed]

133. Sikwal, D.R.; Kalhapure, R.S.; Govender, T. An emerging class of amphiphilic dendrimers for pharmaceutical and biomedical applications: Janus amphiphilic dendrimers. Eur. J. Pharm. Sci. 2017, 97, 113-134. [CrossRef] [PubMed]

134. Agrawal, U.; Mehra, N.K.; Gupta, U.; Jain, N.K. Hyperbranched dendritic nano-carriers for topical delivery of dithranol. J. Drug Target. 2013, 21, 497-506. [CrossRef]

135. Damiani, G.; Pacifico, A.; Linder, D.M.; Pigatto, P.D.M.; Conic, R.; Grada, A.; Bragazzi, N.L. Nanodermatology-based solutions for psoriasis: State-of-the art and future prospects. Dermatol. Ther. 2019, 32, 1-15. [CrossRef] [PubMed] 
136. Lapteva, M.; Mondon, K.; Möller, M.; Gurny, R.; Kalia, Y.N. Polymeric micelle nanocarriers for the cutaneous delivery of tacrolimus: A targeted approach for the treatment of psoriasis. Mol. Pharm. 2014, 11, 2989-3001. [CrossRef] [PubMed]

137. Teixeira, M.C.; Carbone, C.; Souto, E.B. Beyond liposomes: Recent advances on lipid based nanostructures for poorly soluble/poorly permeable drug delivery. Prog. Lipid Res. 2017, 68, 1-11. [CrossRef]

138. Doktorovova, S.; Kovacevic, A.B.; Garcia, M.L.; Souto, E.B. Preclinical safety of solid lipid nanoparticles and nanostructured lipid carriers: Current evidence from in vitro and in vivo evaluation. Eur. J. Pharm. Biopharm. 2016, 108, 235-252. [CrossRef] [PubMed]

139. Clares, B.; Calpena, A.C.; Parra, A.; Abrego, G.; Alvarado, H.; Fangueiro, J.F.; Souto, E.B. Nanoemulsions (NEs), liposomes (LPs) and solid lipid nanoparticles (SLNs) for retinyl palmitate: Effect on skin permeation. Int. J. Pharm. 2014, 473, 591-598. [CrossRef]

140. Wadhwa, S.; Singh, B.; Sharma, G.; Raza, K.; Katare, O.P. Liposomal fusidic acid as a potential delivery system: A new paradigm in the treatment of chronic plaque psoriasis. Drug Deliv. 2016, 23, 1204-1213. [CrossRef]

141. Hua, S. Lipid-based nano-delivery systems for skin delivery of drugs and bioactives. Front. Pharmacol. 2015, 6, 2011-2015. [CrossRef]

142. Jain, A.; Doppalapudi, S.; Domb, A.J.; Khan, W. Tacrolimus and curcumin co-loaded liposphere gel: Synergistic combination towards management of psoriasis. J. Control. Release 2016, 243, 132-145. [CrossRef]

143. Ainbinder, D.; Paolino, D.; Fresta, M.; Touitou, E. Drug delivery applications with ethosomes. J. Biomed. Nanotechnol. 2010, 6, 558-568. [CrossRef] [PubMed]

144. Zhang, Y.T.; Shen, L.N.; Zhao, J.H.; Feng, N.P. Evaluation of psoralen ethosomes for topical delivery in rats by using in vivo microdialysis. Int. J. Nanomed. 2014, 9, 669-678. [CrossRef]

145. Mueller, R.H.; Mehnert, W.; Souto, E.B. Solid Lipid Nanoparticles (SLN) and Nanostructured Lipid Carriers for Dermal Delivery. Adv. Drug Deliv. Rev. 2006, 37. [CrossRef]

146. Almeida, A.J.; Souto, E. Solid lipid nanoparticles as a drug delivery system for peptides and proteins. Adv. Drug Deliv Rev. 2007, 59, 478-490. [CrossRef] [PubMed]

147. Teeranachaideekul, V.; Souto, E.B.; Muller, R.H.; Junyaprasert, V.B. Physicochemical characterization and in vitro release studies of ascorbyl palmitate-loaded semi-solid nanostructured lipid carriers (NLC gels). J. Microencapsul. 2008, 25, 111-120. [CrossRef] [PubMed]

148. Fernandes, A.R.; Martins-Gomes, C.; Santini, A.; Silva, A.M.; Souto, E.B. Chapter 9-Psoriasis vulgaris-Pathophysiology of the disease and its classical treatment versus new drug delivery systems. In Design of Nanostructures for Versatile Therapeutic Applications; Grumezescu, A.M., Ed.; William Andrew Publishing: Norwich, NY, USA, 2018; pp. 379-406. [CrossRef]

149. Pradhan, M.; Singh, D.; Singh, M.R. Development characterization and skin permeating potential of lipid based novel delivery system for topical treatment of psoriasis. Chem. Phys. Lipids 2015, 186, 9-16. [CrossRef]

150. Shimojo, A.A.M.; Fernandes, A.R.V.; Ferreira, N.R.E.; Sanchez-Lopez, E.; Santana, M.H.A.; Souto, E.B. Evaluation of the Influence of Process Parameters on the Properties of Resveratrol-Loaded NLC Using 2(2) Full Factorial Design. Antioxidants $2019,8,272$. [CrossRef] [PubMed]

151. Souto, E.B.; Doktorovova, S. Chapter 6-Solid lipid nanoparticle formulations pharmacokinetic and biopharmaceutical aspects in drug delivery. Methods Enzym. 2009, 464, 105-129. [CrossRef]

152. Shrotriya, S.N.; Ranpise, N.S.; Vidhate, B.V. Skin targeting of resveratrol utilizing solid lipid nanoparticle-engrossed gel for chemically induced irritant contact dermatitis. Drug Deliv. Transl. Res. 2017, 7, 37-52. [CrossRef] [PubMed]

153. Avasatthi, V.; Pawar, H.; Dora, C.P.; Bansod, P.; Gill, M.S.; Suresh, S. A novel nanogel formulation of methotrexate for topical treatment of psoriasis: Optimization, in vitro and in vivo evaluation. Pharm. Dev. Technol. 2016, 21, 554-562. [CrossRef]

154. Donnelly, R.F.; Raghu, T.; Singh, R.; Woolfson, A.D. Microneedle-based drug delivery systems: Microfabrication, drug delivery, and safety. Drug Deliv. 2010, 17, 187-207. [CrossRef]

155. Larrañeta, E.; Lutton, R.E.M.; Woolfson, A.D.; Donnelly, R.F. Microneedle arrays as transdermal and intradermal drug delivery systems: Materials science, manufacture and commercial development. Mater. Sci. Eng. R Rep. 2016, 104, 1-32. [CrossRef]

156. Zhao, Z.; Chen, Y.; Shi, Y. Microneedles: A potential strategy in transdermal delivery and application in the management of psoriasis. RSC Adv. 2020, 10, 14040-14049. [CrossRef]

157. Ishihara, T.; Kubota, T.; Choi, T.; Takahashi, M.; Ayano, E.; Kanazawa, H.; Higaki, M. Polymeric nanoparticles encapsulating betamethasone phosphate with different release profiles and stealthiness. Int. J. Pharm. 2009, 375, 148-154. [CrossRef]

158. Ourique, A.F.; Pohlmann, A.R.; Guterres, S.S.; Beck, R.C.R. Tretinoin-loaded nanocapsules: Preparation, physicochemical characterization, and photostability study. Int. J. Pharm. 2008, 352, 1-4. [CrossRef]

159. Pandi, P.; Jain, A.; Kommineni, N.; Ionov, M.; Bryszewska, M.; Khan, W. Dendrimer as a new potential carrier for topical delivery of siRNA: A comparative study of dendriplex vs. lipoplex for delivery of TNF- $\alpha$ siRNA. Int. J. Pharm. 2018, 550, 240-250. [CrossRef] [PubMed]

160. Lapteva, M.; Santer, V.; Mondon, K.; Patmanidis, I.; Chiriano, G.; Scapozza, L.; Gurny, R.; Möller, M.; Kalia, Y.N. Targeted cutaneous delivery of ciclosporin A using micellar nanocarriers and the possible role of inter-cluster regions as molecular transport pathways. J. Control. Release 2014, 196, 9-18. [CrossRef]

161. Nagle, A.; Goyal, A.K.; Kesarla, R.; Murthy, R.R.; Nagle, A.; Goyal, A.K.; Kesarla, R.; Murthy, R.R. Efficacy study of vesicular gel containing methotrexate and menthol combination on parakeratotic rat skin model Efficacy study of vesicular gel containing methotrexate and menthol combination on parakeratotic rat skin model. J. Liposome Res. 2011, 2104. [CrossRef] 
162. Kumar, R.; Dogra, S.; Amarji, B.; Singh, B.; Kumar, S.; Sharma; Vinay, K.; Mahajan, R.; Katare, O.P. Efficacy of Novel Topical Liposomal Formulation of Cyclosporine in Mild to Moderate Stable Plaque Psoriasis: A Randomized Clinical Trial. JAMA Dermatol. 2016, 152, 807-815. [CrossRef] [PubMed]

163. Ostergaard, N.; Jorgensen, L.; Hansen, J.; Vermehren, C.; Frokjaer, S.; Foged, C. Targeting of liposome-associated calcipotriol to the skin: Effect of liposomal membrane fluidity and skin barrier integrity. Int. J. Pharm. 2011, 416, 478-485. [CrossRef]

164. Chen, M.; Kumar, S.; Anselmo, A.C.; Gupta, V.; Slee, D.H.; Muraski, J.A.; Mitragotri, S. Topical delivery of Cyclosporine A into the skin using SPACE-peptide. J. Control. Release 2015, 199, 190-197. [CrossRef]

165. Li, G.; Fan, Y.; Fan, C.; Li, X.; Wang, X.; Li, M.; Liu, Y. Tacrolimus-loaded ethosomes: Physicochemical characterization and in vivo evaluation. Eur. J. Pharm. Biopharm. 2012, 82, 49-57. [CrossRef] [PubMed]

166. Agrawal, U.; Gupta, M.; Vyas, S.P. Capsaicin delivery into the skin with lipidic nanoparticles for the treatment of psoriasis. Artif. Cells Nanomed. Biotechnol. 2015, 43, 33-39. [CrossRef]

167. Sonawane, R.; Harde, H.; Katariya, M.; Agrawal, S.; Sonawane, R.; Harde, H.; Katariya, M.; Agrawal, S. Solid lipid nanoparticlesloaded topical gel containing combination drugs: An approach to offset psoriasis Solid lipid nanoparticles-loaded topical gel containing combination drugs: An approach to offset psoriasis. Expert Opin. Drug Deliv. 2014, 5247. [CrossRef]

168. Doktorovová, S.; Araújo, J.; Garcia, M.L.; Rakovský, E.; Souto, E.B. Formulating fluticasone propionate in novel PEG-containing nanostructured lipid carriers (PEG-NLC). Colloids Surf. B Biointerfaces 2010, 75, 538-542. [CrossRef]

169. Lin, Y.-K. Combination of calcipotriol and methotrexate in nanostructured lipid carriers for topical delivery. Int. J. Nanomed. 2010, $5,117-128$.

170. Tekko, I.A.; Permana, A.D.; Vora, L.; Hatahet, T.; McCarthy, H.O.; Donnelly, R.F. Localised and sustained intradermal delivery of methotrexate using nanocrystal-loaded microneedle arrays: Potential for enhanced treatment of psoriasis. Eur. J. Pharm. Sci. 2020, 152, 105469. [CrossRef] [PubMed]

171. Lee, J.H.; Jung, Y.S.; Kim, G.M.; Bae, J.M. A hyaluronic acid-based microneedle patch to treat psoriatic plaques: A pilot open trial. Br. J. Dermatol. 2018, 178, e24-e25. [CrossRef] [PubMed] 